ENSAYO

\title{
MODELOS, JUEGOS Y ARTEFACTOS SUPUESTOS, PREMISAS E ILUSIONES DE LOS ESTUDIOS ELECTORALES Y DE SISTEMAS DE PARTIDOS EN CHILE (1988-2005)*
}

\begin{abstract}
Alfredo Joignant
Desde mediados de la década del 90 hasta hoy, la producción científica sobre el comportamiento electoral y el sistema de partidos chileno se ha incrementado considerablemente. Es a evaluar el cada vez más vasto trabajo de investigación científica sobre las elecciones y los partidos en Chile a lo que aspira este artículo. Sin embargo, esta evaluación no transita por el camino de contrastar resultados electorales o estadísticos, por ejemplo a través del empleo de diversas técnicas de análisis de datos sobre un mismo objeto. Contraviniendo las rutinas de investigación que tienden a predominar en los estudios electorales y de partidos sobre Chile, lo que se pretende es deconstruir el tipo de razonamiento que acompaña el uso de técnicas estadísticas a menudo muy sofisticadas, así como las categorías que son empleadas por los investigadores. De este modo, la intención es abogar por una sociología política que se toma en serio la necesidad
\end{abstract}

Alfredo Joignant. Profesor asociado, Departamento de Ciencia Política de la Universidad de Chile. Doctor en ciencia política, Universidad de París I PanthéonSorbonne, Francia. Ex presidente de la Asociación Chilena de Ciencia Política (19982000). E-mail: joignant@uchile.cl.

* Quiero agradecer los valiosos comentarios de un anónimo evaluador de este artículo, varios de los cuales recogí, en el entendido que la responsabilidad de lo aquí se dice es enteramente mía. 
de elaborar su objeto de investigación, y que no escatima esfuerzos en deconstruir las nociones y los usos que los investigadores hacen de ellas. Dicho de otra manera, el propósito de este artículo es reivindicar la razón teórica con el fin de interrogar los resultados de que se dispone, y con los que se formulan nuevas estrategias de investigación, aun cuando esto signifique relativizar lo que se cree saber acerca de los partidos, de los sistemas que éstos conforman y de los comportamientos electorales subyacentes en Chile.

Ninguno de los pensamientos que cruzan mi mente, ninguna de las explicaciones, por muy antagónicas que sean, del origen de mi deseo parece afligirme. 'Debo de estar cansado — pienso- - O quizá sea que todo lo que pueda expresarse esté erróneamente formulado'. Mis labios se mueven componiendo y recomponiendo las palabras en silencio. ' $O$ puede que solo lo que no ha sido expresado haya de ser vivido’.

J. M. Coetzee, Esperando a los Bárbaros, (Barcelona: Debolsillo, 2004, p. 55).

\section{Reivindicando la razón teórica}

\section{A}

decir verdad, mi propósito no es muy distinto al de Munck y Verkuilen (2002), quienes, muy brillantemente, emprenden un trabajo de "especificación del significado del concepto” de “calidad de la democracia”, a partir de una reflexión crítica sobre los resultados obtenidos por la investigación estadística (especialmente por Freedom House y Polity IV), aduciendo que dicha especificación "afecta el proceso entero de generación de datos, dado que proporciona el ancla para todas las decisiones subsiguientes” (p. 7). En efecto, de no mediar este esfuerzo a la vez conceptual y metodológico, se corre seriamente el riesgo de "poner el carro estadístico delante del caballo teórico” (Munck y Verkuilen, 2002, p. 23).

Ciertamente, no son sólo estos dos autores quienes se han interesado en discutir teórica y conceptualmente la investigación de naturaleza cuantitativa sobre objetos políticos y electorales, como tampoco son los únicos en haberlo hecho en los Estados Unidos. Prueba de ello es la olvidada contribución de Lazarsfeld a la construcción de "clasificaciones inferenciales” (Lazarsfeld, 1970, pp. 185-227), o más recientemente la interesante 
crítica de Goertz a la escasa atención concedida por la investigación empírica a "la importancia primordial de los conceptos" (Goertz, 2005, p. 1). Por sí solos, estos dos trabajos bastan para invalidar la confusión que podría suscitar el estudio que se leerá a continuación, por ejemplo al inferir de él una crítica teórica y epistemológica a la "ciencia política estadounidense", una entelequia que a ojos vista no existe, sobre todo si se considera que autores tan influyentes como Converse o Sartori también se han abocado a este ejercicio.

En cualquier caso, la crítica que aquí esbozo a los estudios políticos y electorales en Chile se origina en una concepción de la investigación científica que toma en serio el vocabulario conceptual y la teoría que subyace a cualquier empresa de medición, clasificación y formalización de resultados. De modo general, comparto plenamente la observación de Goertz según la cual "los conceptos son teorías acerca de la ontología”, esto es, construcciones racionales a propósito de "los elementos constitutivos fundamentales de un fenómeno” (Goertz, 2005, p. 5). Como tales, estas teorías no constituyen construcciones arbitrarias del investigador, en la medida en que la unificación racional de los distintos componentes de un objeto limita significativamente los riesgos de arbitrariedad. Pero al mismo tiempo, la construcción de teorías no constituye un fin en sí mismo de las ciencias sociales, sobre todo si se pretende comprender y explicar la "acción" o el "comportamiento" de tal o cual actor, el funcionamiento de un "sistema" (por ejemplo de partidos) o los "efectos" de dispositivos de reconversión de votos en escaños (pongamos por caso el binominal). En estos casos, como en tantos otros, la medición o la formalización de resultados es un ejercicio que no puede soslayar la construcción teórica y el vocabulario conceptual, ni menos confundir el lenguaje de las variables con el idioma conformado por las categorías de análisis. En tal sentido, los objetos sobre los que trabaja el cientista social, y en este caso el cientista político, distan mucho de ser objetos al estado bruto cuya naturaleza práctica no presentaría mayores problemas para la investigación científica. Como bien lo muestra la sociología de la ciencia a la cual adhiero, el objeto de estudio requiere ser construido, y no sólo ser definido, lo que en cualquier caso debiese dar lugar a definiciones provisionales. En tal sentido, la construcción metódica del objeto de estudio por la vía de la ruptura respecto de los significados prácticos con los que éste tiende a imponerse ante el investigador, supone un trabajo de objetivación, el cual es imposible de lograr sin el uso de teorías y conceptos. Esta es la razón por la cual la construcción del objeto se logra al cabo de su conquista, y no al precio del sometimiento de la 
mirada del investigador ante su carácter socialmente evidente: para una aproximación clásica a la construcción del objeto, cf. Bourdieu, Passeron y Chamboredon (1968); para un enfoque explícitamente epistemológico, cf. Passeron (1991).

Buena parte de la investigación empírica sobre objetos políticos y electorales en Chile se ha caracterizado por una cierta indiferencia ante la importancia de la teoría y de los conceptos, y ha sido generalmente renuente a reflexionar acerca de la manera de cómo los construye, más allá de las definiciones estadísticas o taxonómicas que suelen ser solicitadas. No pretendo sostener que estas investigaciones se encuentren regidas por la lógica del error. Muy por el contrario. A menudo se trata de estudios que proporcionan valiosa información y sugerentes demostraciones. Sin embargo, en la medida en que son investigaciones que se presentan un poco a la manera del arte según Durkheim, esto es “práctica pura sin teoría”, mi propósito es sugerir a través de la deconstrucción de la literatura todo lo que se puede ganar, y conquistar, reivindicando la razón teórica, sin que esto suponga renunciar a la elaboración de indicadores, a la medición y la formalización de resultados.

En lo que se refiere a la investigación sobre las elecciones y los partidos chilenos, incluso antes de interrogar los datos obtenidos a partir de sofisticadas técnicas estadísticas, es posible observar usos imprecisos del lenguaje científico, lo que impacta no sólo en las posteriores mediciones, sino que en las interpretaciones de los resultados, al pasar por el tamiz de un lenguaje que oscila entre su condición de idioma natural destinado a usos ordinarios y prácticos, y su estado de lengua abstracta que hace posible la teorización y conceptualización del objeto pretendidamente estudiado. Apoyémonos en tres ejemplos. Cada uno de ellos se refiere a distintos objetos políticos, pero dependiendo de cómo estos son nombrados, se desprenden innumerables consecuencias analíticas, al sesgar en estos tres casos la interpretación de los datos empíricos producidos por la investigación.

El primer ejemplo, tal vez el más simple y elocuente de todos, se refiere al uso impreciso, a la vez que anacrónico, de la categoría de "régimen” en su faz “no democrática” y “dictatorial”. Es así como se puede apreciar, en un reciente trabajo de Colomer (2004a) sobre la extensión del sufragio en América Latina realizado a partir de modelizaciones espaciales, afirmaciones sumamente discutibles según las cuales Chile (entre 1824 y 1946), al igual que otros países de la región en períodos distintos, exhibía rasgos propios de "regímenes políticos no democráticos pero basados en 
elecciones", sin que ello signifique que se trate de "regímenes dictatoriales" (p. 30). Como es fácil constatar, hay en Colomer un uso excesivamente impreciso de la noción de régimen para caracterizar el caso chileno en el período en cuestión, puesto que el adjetivo "no democrático" es sencillamente vago al no explicitar atributos positivos de funcionamiento de dicho régimen, con lo cual se desemboca en un verdadero oxímorom al agregar el componente "basado en elecciones". Sin embargo, más problemática aún es la curiosa distinción que Colomer establece entre este confuso régimen político de lo que no es, un "régimen dictatorial”, con lo cual terminamos ignorando conceptualmente todo acerca de las formas y del funcionamiento del régimen (sin calificativos) chileno durante... ¡122 años! Esta imprecisión se explica por el uso a-histórico de la categoría de “régimen”, precisamente porque la aproximación de Colomer se funda en una sofisticada modelización espacial que hace posible la interpretación de las distintas velocidades de las reformas de extensión del sufragio en América Latina en general, y en Chile en particular, a partir de un ejercicio de localización de "la posición de los nuevos votantes” (p. 38) que se incorporan más o menos rápidamente al electorado sin interrogar la historicidad del proceso, lo que es muy distinto de razonar en términos de temporalidades lentas o veloces. Puede entonces entenderse la severa crítica de Valenzuela (2004) al enfoque de Colomer, un autor que destaca numerosas imprecisiones y no pocos errores históricos, aunque sin sacar todas las consecuencias conceptuales que se desprenden del uso de un modelo espacial para dar cuenta de la relación entre ampliación del sufragio y crisis de régimen en América Latina.

El segundo ejemplo concierne el uso rutinizado de nociones tan difundidas en historia, sociología y ciencia política como las de "populismo", "carisma” y "caciquismo", con las cuales se señalan formas de liderazgo y modos particulares de organización del poder político que, al ser nombrados a partir de categorías establecidas, presumen interpretaciones y significados que serían lo suficientemente unívocos como para evitar el trabajo de especificación histórica, cultural y conceptual. Es así como Montes, Mainwaring y Ortega (2000) constatan la existencia de "una fuerte tradición antipartidaria" en Chile, de la cual tres presidentes (Arturo Alessandri, Carlos Ibáñez del Campo y Jorge Alessandri) son una clara expresión, del mismo modo que aquella otra tradición de "contendores presidenciales populistas o tecnócratas” (p. 799). Pero, ¿en qué sentido estos autores emplean el adjetivo de "populista"? Aparentemente, en el sentido de no pertenencia a partidos políticos, lo que sería congruente con la supuesta tradición antipartidaria que ellos mismos constatan en Chile. Prueba de ello 
sería que de las 11 elecciones presidenciales que tuvieron lugar entre 1932 y 1999, en 6 de ellas los "candidatos independientes" obtuvieron el 30\% de los votos (p. 799). Formalmente, la argumentación es impecable, permitiéndoles sacar conclusiones acerca del "sistema de partidos" chileno, en la medida en que "el caudillismo, el populismo y el presidencialismo" seguirían siendo "componentes" esenciales del mismo (p. 803). Sin embargo, conceptualmente esta misma argumentación se revela extremadamente débil y problemática. ¿Por qué? Porque la asociación entre "independientes” y candidatos presidenciales "populistas" como si fuesen sinónimos es demasiado estrecha, al aludir únicamente a un aspecto formal del liderazgo (su carácter "independiente"), sin dar cuenta de sus modalidades de ejercicio a través de prácticas políticas específicas. En tal sentido, resulta arriesgado asentar la tesis de una "tradición antipartidaria" en Chile, lo que se vuelve tanto más problemático cuanto mayor es la vaguedad del uso conceptual del "populismo", al asimilarlo sin mayor explicación al "caudillismo" y al "personalismo", pasando además completamente por alto siquiera una alusión a las especificidades de las coyunturas históricas que hicieron posible la emergencia de los dos Alessandri y de Ibáñez.

Esta misma imprecisión se observa a propósito de la noción de "carisma”, como si esta fuese lo suficientemente elocuente. Es así como, en un interesante artículo sobre la distribución del riesgo y la política de seguros inventada por la Concertación con el fin de asegurar una eficiente oferta electoral en el marco del sistema binominal, Carey y Siavelis (2005) elaboran medidas de la "solidez" de los candidatos, las que a su vez "reflejan combinaciones de dos tipos de características: calidad inherente (carisma, calificaciones, preeminencia personal), y esfuerzo en nombre de la campaña” (p. 9). Hay allí, sin duda, un uso laxo de la noción de "carisma”, usándola más como adjetivo que como concepto, lo que permite a los autores volver verosímil la demostración de la existencia de un tipo particular de política por parte de la Concertación. Sin embargo, al inscribir el carisma dentro de cualidades "inherentes" de los candidatos, Carey y Siavelis recogen implícitamente uno de los significados posibles de la noción de carisma en sociología y ciencia política. En efecto, así planteada, la argumentación de los autores se funda en una concepción sustancialista del carisma, al hacer como si este atributo fuese una característica intrínseca de algunos individuos excepcionales, en circunstancias que se trata de un recurso por definición inestable, al ser el resultado complejo de lógicas sociales de situación. Ello explica que, en ausencia de una sociología política del carisma, los autores se contenten con el uso de lo que parece ser un adjetivo (y no un concepto), haciendo la economía del análisis de la situación que hace posi- 
ble la existencia de actores carismáticos ${ }^{1}$. Puede entonces entenderse lo arriesgado de sacar conclusiones acerca de problemáticas más generales (como por ejemplo el uso racional y eficaz del sistema binominal por parte de la Concertación) a partir del supuesto de elocuencia y transparencia que rodearía al carisma. Por lo demás, es este mismo uso analítico del carisma el que se observa en Payne, Zovatto, Carrillo y Allamand (2003), quienes afirman sin más que "la participación electoral puede oscilar en respuesta a factores coyunturales como el carisma de los distintos candidatos" (p. 54), lo que equivale a hacer del carisma un principio de explicación de los vaivenes de la participación electoral, suponiendo que el carisma es una noción que todo el mundo entiende, y del mismo modo.

El tercer ejemplo se refiere directamente a las propiedades y características del sistema binominal. Pero, partiendo por lo que debiese ser el comienzo, ¿sabemos exactamente de qué tipo de sistema electoral estamos hablando? La respuesta es: no siempre. En efecto, si bien la mayor parte de la literatura especializada lo clasifica correctamente como parte de los sistemas de representación proporcional, poniendo el acento en su especificidad (un sistema que, visto desde su magnitud $(\mathrm{M}=2)$, es la más pequeña concebible en un sistema proporcional), existen no pocos autores que lo tipifican como un "sistema binominal mayoritario" (Tironi y Agüero, 1999, p. 162; Pastor, 2004, p. 38), a veces secundado por un tecnicismo: "por lista” (Valenzuela, 2005, p. 53), aun cuando en este último caso el autor se corrige poco después al precisar que "el binominalismo mayoritario por lista" es "más bien un sistema proporcional que uno mayoritario" (p. 55). En el origen de estas vacilaciones subyace, probablemente, el impacto de lo inédito de este sistema de representación a lo largo de toda la historia electoral chilena. Pero más profundamente, este titubeo es también el fruto de una confusión entre lo que es una propiedad formal — su pequeña magnitud—, y los efectos mecánicos de corte mayoritario que tienden a ser producidos por el sistema binominal. Es precisamente esta confusión entre propiedades y efectos la que se trasluce en el importante estudio de Payne, Zovatto,

${ }^{1}$ A este respecto, el lector podrá leer en paralelo el ambiguo trabajo de Weber (1995) sobre la "dominación carismática” concebida como tipo ideal (p. 320 y sigs.), y su rigurosa sociología de la religión (especialmente aquellas brillantes páginas referidas al profeta como figura histórica del liderazgo carismático (Weber, 1995, tomo 2, p. 145 y sigs.)). En tal sentido, la aproximación antropológica del carisma de Lindholm (1992) es pertinente en esta discusión, al concebirlo "ante todo [como] una relación” y no como resultado de "características físicas" (p. 22), ni menos como "una ilusión” (p. 21), afirmando que es necesario situar cualquier estudio del carisma en un contexto, mostrando "la relación entre las circunstancias y la evolución de una relación carismática” (p. 23). 
Carrillo y Allamand (2003), al describir el resultado, o si se quiere su efecto presunto: "el resultado es una forma particular de sistema mayoritario que favorece a los partidos más grandes y en especial al segundo partido (o coalición) más importante” (p. 96). Esta afirmación es empíricamente correcta, pero el efecto mecánico del sistema binominal, no obstante ser corroborado por los resultados electorales desde 1989 en adelante, no se explica por sus propiedades formales constantes (un sistema por lista con voto preferente al interior de ella, en el marco de una magnitud idéntica [M=2] en todos los distritos diputacionales y circunscripciones senatoriales).

Es probable que para muchos autores esta discusión conceptual sea al final de cuentas inútil, puesto que no constituye un obstáculo para emprender mediciones acerca de los efectos de tal o cual sistema electoral, o de la incidencia de determinados factores (como por ejemplo el carisma) en las tasas de participación electoral y en los usos del binominal por la vía de un sistema implícito de recompensas diseñado y empleado por una coalición (en este caso, la Concertación). Esto sería cierto si el trabajo de medición, a menudo realizado a partir de sofisticadas metodologías y técnicas estadísticas, no supusiese una interpretación de los resultados obtenidos en un momento que es lógicamente posterior. Y es allí en donde se expresa con toda nitidez la necesidad de la teoría y del vocabulario conceptual, sin perjuicio de que incluso antes de medir las preguntas de investigación desempeñan un papel esencial. ¿Es posible formularlas eludiendo la especificación de tal o cual noción, categoría o concepto? Más profundamente, ¿hasta qué punto la ausencia de especificación conceptual no transforma tal o cual "factor" en variable implícita? Finalmente, ¿puede ser posible una interpretación rigurosa de los resultados alcanzados al cabo de un importante despliegue de técnicas estadísticas sin la presencia de un lenguaje conceptual riguroso que es propio del pensamiento científico? En estas preguntas, existe una fuerte presunción de que la respuesta sólo puede ser negativa.

Del mismo modo en que es posible apreciar una cierta indiferencia por la teoría y el lenguaje conceptual en los estudios electorales y sobre sistemas de partidos en Chile, resulta al mismo tiempo imposible no constatar la presencia de supuestos que funcionan en el modo de la evidencia, sin siquiera interrogarse acerca de su pertinencia empírica. A este respecto, el volumen de supuestos que son solicitados es considerable, razón por la cual escogeremos sólo algunos con el fin de mostrar de qué modo éstos participan de la interpretación de resultados, y originan explicaciones más o menos plausibles.

Si bien son pocos los estudios que basan buena parte de su argumentación en supuestos tan vagos que tornan imposible la evaluación de 
su pertinencia empírica, vale la pena detenerse en algunos de ellos para mostrar de qué modo pueden proporcionar un simulacro de la explicación. Es así como el influyente trabajo del PNUD acerca de La Democracia en América Latina (2004) se inicia con una curiosa referencia a una inverificable teoría de los “impulsos”, según la cual “en los distintos ámbitos de la vida” estaríamos orientados, por no decir determinados, por un "vital” impulso: "el impulso por la dominación y por el poder que permite ejercerla” (p. 33). Así formulada, sería muy fácil proseguir por la senda de la psicología espontánea, con el fin de instalar a modo de trasfondo de la política latinoamericana una dimensión psíquica universal de la cual, todos, seríamos presa y parte. Si bien una formulación de esta naturaleza se presta naturalmente para la crítica, no es posible al mismo tiempo desconocer su función de reproducción de sentidos comunes referidos a cómo interpretar las luchas entre actores individuales y colectivos, sean éstos dirigentes, líderes más o menos “carismáticos”, “populistas” o “caudillistas”, o derechamente entre partidos, cuya regular interacción competitiva estaría fuertemente predeterminada por “impulsos” de dominación o de poder. Aún más. Esta teoría de los impulsos podría incluso permitir “explicar” la génesis de liderazgos fuertes, así como fenómenos de movilización y de politización de los ciudadanos que son fácilmente recogidos por los medios masivos de comunicación. En tal sentido, esta referencia a los impulsos puede operar como trasfondo constante de los comportamientos políticos, o si se quiere como "explicación” de sucesos y conductas que no se dejan entender de modo simple.

En tal sentido, las referencias recurrentes a la “ideologización” que es posible detectar en un sinnúmero de estudios electorales y de partidos, particularmente sobre Chile, no es muy distinta de esta teoría de los impulsos. Como es bien sabido, es a Sartori (1980) a quien se le debe reconocer el mérito de haber hecho de la ideología uno de los elementos de diferenciación y de distanciamiento relativo entre partidos que pugnan entre sí de modo regular, al punto de conformar sistemas de interacción más o menos estables, dependiendo del número de competidores y de sus características (partidos anti-sistema, capacidades variables de "chantaje", modalidades leales o semi-leales de oposición, etc.). Si bien el enfoque de Sartori es de naturaleza sistémica que, como tal, es difícilmente asimilable a una teoría de los impulsos que presupone la existencia de actores gobernados por pasiones y pulsiones, la “ideologización” y la “polarización” de la lucha política que la acompaña fueron retraducidos como principios de comportamiento por Valenzuela (s/f), a continuación del influyente trabajo de Linz (1987), con el fin de explicar el quiebre democrático chileno. A modo de prueba del supuesto impacto de esta ideologización en Chile, Valenzuela no duda en 
referirse a fenómenos masivos de movilización (manifestaciones y violencia callejera, huelgas, comportamientos electorales), haciendo como si las conductas de estos manifestantes, violentistas, huelguistas y electores estuviesen pre-determinadas por ideologías polarizadoras. En tal sentido, la teoría de los impulsos adquiere visos de realidad al volverse ideología, y tal vez culturas políticas masivas. Si bien esta aproximación fue brillantemente rebatida por Bermeo (2003) al interrogar lo que personas comunes y corrientes (ordinary people) hacen, y dejan de hacer, en "tiempos extraordinarios”, el hecho es que, llevada al plano electoral, aún sigue funcionando como supuesto cuando se trata de explicar, por ejemplo, el comportamiento de los votantes.

Tal es el caso de la explicación del comportamiento electoral de una parte de los adherentes del NO en el plebiscito de 1988 que es proporcionada por Panzer y Paredes (1991), en un trabajo en donde los autores intentan hacer una estimación del rol de la ideología. Es así como Panzer y Paredes proponen un modelo de estimación del rol de la ideología asumiendo que "los partidos políticos y los votantes" no responden a issues económicos, sino que fundan su comportamiento electoral en "doctrinas rígidas", para lo cual la ideología es indirectamente abordada "a través de la persistencia" a lo largo del tiempo "de los resultados electorales, independientemente de la performance económica” (p. 55). Así, los autores detectan que la única variable significativa para dar cuenta del rol de la ideología en 1988 es la relación negativa entre la votación de Allende en 1970 y la votación de Pinochet en 1988, lo que demostraría una mayor ideologización de los seguidores de Allende en relación a los partidarios de Alessandri en 1970 y de la CODE en 1973 (p. 56). Si bien la demostración estadística es impecable, ¿es razonable inferir de esa relación negativa la persistencia de comportamientos electorales que se originan en una ideología? Y en primer lugar, ¿en qué sentido se está empleando la noción de ideología? ¿Hasta qué punto no hay en el uso de la ideología y de su sustantivo (la ideologización) por parte de estos autores una reificación, al hacer como si todos los que fueron votantes de Allende en 1970 constituyesen un grupo homogéneo 18 años más tarde? ¿Qué nos permite afirmar, más allá del electorado estadístico que es construido por los autores, que los electores por el NO de 1988 siguen estando idénticamente orientados por una ideología previa? ¿Por qué no ver en esta continuidad estadística un signo de lealtad electoral que no necesariamente presupone un principio de producción del voto de naturaleza ideológica? Si es posible formular estas preguntas, es porque en Panzer y Paredes, al igual que en tantos otros autores, se aprecia un uso poco riguroso 
de la noción de ideología, al ser erigida como variable independiente sin interrogar previamente su pertinencia conceptual.

Mucho más frecuente es el uso del eje derecha-izquierda en la literatura sobre preferencias electorales y sistema de partidos en Chile, al permitir formular legítimas preguntas de investigación acerca de la estabilidad o de la discontinuidad del comportamiento electoral a lo largo del tiempo, del modo de configuración del sistema de partidos que resulta de este eje y de la eventual producción de decisiones de voto que podrían originarse en estas categorías espaciales. Si el eje derecha-izquierda no plantea los mismos problemas conceptuales que a los que da lugar el uso de nociones tales como "carisma”, "populismo”, "ideologización” o “polarización”, ello se debe a que el eje en cuestión está formado por categorías espaciales que cumplen la función de organizar el mundo político, y por sobre todo de darle sentido. De este modo, el eje derecha-izquierda admite innumerables usos, como por ejemplo hacer estimaciones razonables sobre las alianzas posibles o inverosímiles entre partidos, establecer mediciones de la distancia relativa que separa a fuerzas políticas organizadas e indagar acerca de las posibilidades de identificación de los electores con las categorías que conforman el eje (generalmente a través de preguntas de encuesta, solicitando recurrentemente escalas tipo Likert, o mediante análisis de nivel agregado que, dependiendo de la posición ocupada por tal o cual candidato cuya identidad se asocia a una etiqueta partidaria, dotan a la "ideología" de realidad en la medida en que ésta es localizable en alguna parte del eje derecha-izquierda). Si bien las técnicas y metodologías de análisis empleadas sobre el eje son muy variadas, su común denominador radica en que el investigador no requiere proceder a un trabajo de especificación conceptual. Esto no quiere decir, sin embargo, que el eje derecha-izquierda no plantee problemas de uso o interpretación. Simplemente, las dificultades que se asocian al eje, independientemente de la impecabilidad estadística de los resultados que éste proporciona una vez constituido como variable, son de otra índole.

En primer lugar, huelga reconocer que los significados que se asocian al eje derecha-izquierda están sujetos a variaciones históricas. En tal sentido, cabe seriamente hacerse la pregunta acerca de la utilidad de agrupar y agregar votaciones, a lo largo de series extendidas de tiempo, en torno a alianzas dóxicamente situadas en la izquierda, el centro y la derecha a más de 30 o 40 años de distancia. Como es bien sabido, Scully y Valenzuela (1993) muestran, tomando en consideración los resultados de las elecciones municipales de 1992, cómo éstos reflejan una sorprendente continuidad respecto de la fuerza electoral exhibida por los partidos que se situaban en la izquierda, el centro y la derecha en 1970, a partir de la astucia de sumar la 
votación individual de los partidos en función de "cómo estaban constituidas [sus] alianzas en 1970” (p. 206). Esta estrategia basada en la mera adición de sufragios por alianzas que, en 1992, no existen respecto de 1970, permite a los autores asentar como verosímil el juicio de continuidad de lo que se conoce en Chile como los tres tercios electorales (cada uno de los cuales corresponde a la dimensión electoral de la izquierda, del centro y de la derecha, respectivamente), aun cuando el propio Valenzuela reconoce en un artículo posterior (con mucha razón) que estos tres tercios proporcionan una imagen aproximativa de las correlaciones de fuerza así aludidas, en la medida en que la izquierda siempre constituyó el tercio más pequeño (Valenzuela, 1995)... con lo cual deja de ser posible seguir hablando de tercios. ¿Es posible sostener, seriamente, que esta mera agregación de resultados permite asentar un juicio de continuidad de las preferencias electorales? A decir verdad, todo parece indicar que la agregación de resultados por alianzas — históricamente inverosímiles en 1992 - se asemeja fuertemente a una construcción artefactual que se torna tanto más plausible cuanto mayor es su asentamiento en la creencia, profundamente arraigada en Chile entre algunos analistas, de que los tres tercios no sólo habrían existido, sino que seguirían existiendo. En efecto, resulta ser de dudosa utilidad eludir la cuestión de la performance electoral de partidos individuales realmente reunidos bajo una misma alianza, cuando esta alianza de partidos dejó de existir en un momento posterior de la comparación. Como es sabido, no es lo mismo competir solos que en sociedad efectiva con otros partidos: mal que mal, es posible hipotetizar que una parte de la votación alcanzada por una coalición se explica por el hecho de competir en calidad de alianza de partidos debidamente constituida. Pero además, resulta problemático agregar votaciones por alianzas que no son siempre reales sin distinguir el carácter local de una elección municipal y el componente nacional que se desprende de una elección legislativa, y a fortiori, presidencial. Aun más. El ejercicio aditivo de votaciones obtenidas en distintos momentos del tiempo no puede pasar por alto la incidencia de sistemas electorales completamente diferentes, como tampoco puede eludir la referencia, correctamente destacada por Bermeo para explicar las variaciones electorales que se observan en Chile entre 1970 y 1973², al “cambio dramático del tamaño del electorado”, el que se incrementa en alrededor de 1.280 .000 personas respecto de 1969

\footnotetext{
${ }^{2}$ Mientras que, en 1970, el candidato presidencial de la Unidad Popular Salvador Allende alcanzaba poco más del 36\% de los votos, esta misma coalición (levemente ampliada por la incorporación de la Izquierda Cristiana a esta alianza de partidos de izquierda en 1971) obtiene alrededor del $44 \%$ de los votos en la elección municipal de marzo de 1973.
} 
(Bermeo, 2003, p. 162), una constatación pertinente que obliga a tomar seriamente en cuenta la ampliación del electorado en torno a 8 millones de votantes en 1992. Más profundamente, lo que revela esta estrategia de análisis de resultados electorales entre periodos muy distantes del tiempo es la completa omisión de las transformaciones históricas que afectan los significados del eje derecha-izquierda, no sólo como consecuencia de la prolongada dictadura chilena (1973-1990), sino también como efecto de las mutaciones de las categorías constitutivas del eje a continuación de sucesos de impacto político y cultural a escala mundial (caída del Muro de Berlín en 1989, desintegración de la URSS, término de la denominada Guerra Fría, etc.). No puede entonces sorprender que este uso de los resultados electorales se asemeje mucho a lo que Bourdieu llamaba un "artefacto", esto es, una construcción social más o menos deliberada de objetos artificiales que, gracias a los signos exteriores de la verosimilitud, permite concebirlos en el modo de la evidencia ${ }^{3}$.

¿Qué pueden significar las categorías de izquierda, centro y derecha cuando éstas son nominalmente comparadas entre dos o más momentos históricos? Al hablar de la izquierda, del centro y de la derecha en 1970 y en 1992, ¿estamos realmente hablando de lo mismo? Ciertamente no. Como bien lo señala Siavelis, "el significado de derecha, centro e izquierda en Chile ha sido transformado a través de la moderación de los partidos y de las plataformas partidarias. Así, en términos cualitativos, cuando un votante dice que es un izquierdista, el significado de 'izquierdista' es diferente al de 1973" (Siavelis, 2002a, p. 96), del mismo modo que la "coreografía de la votación” será distinta cuando la cámara secreta (originalmente llamada "pupitre aislado") aun no forma parte del paisaje regular de ejercicio del sufragio universal que cuando sí existe (Valenzuela, 1998, p. 275; asimismo, Joignant, 2001 y 2002), con todas las consecuencias que ello implica para electores de izquierda que paulatinamente se reconocen y se identifican como tales a medida que el secreto del sufragio se encuentra materialmente garantizado, y no sólo formalmente. Y sin embargo, la tácita atribución de valor histórico constante y de una regular pertinencia política al eje derecha-izquierda sigue presente en la literatura sobre comportamiento electoral y sistema de partidos en Chile.

Probablemente, una parte de la explicación de este uso a-histórico del eje derecha-izquierda y de sus categorías radica en la considerable aceptación de la que gozan los modelos espaciales del voto, tras la duradera

${ }^{3}$ Sin duda, es en su célebre trabajo sobre la "opinión pública” en donde se encuentran expuestas con mayor claridad las lógicas sociales de construcción de esta categoría artefactual (Bourdieu, 1984). 
influencia ejercida por Downs en ciencia política. Es este autor, en efecto, quien contribuyó a instalar la modelización espacial como procedimiento privilegiado para el análisis electoral, suponiendo que "las preferencias políticas pueden ser ordenadas desde la izquierda a la derecha en una manera acordada por todos los votantes”, adaptando la concepción espacial del mercado de Hotelling constituida por "una escala lineal que va de cero a 100” (Downs, 1957, p. 115). Al proceder de este modo, una vez más se pasa por alto la pregunta de los significados que los electores confieren tanto al eje como a sus categorías, cualesquiera sean éstas, así como la interrogante acerca de los usos que los votantes pueden hacer de esta escala. Esta omisión no sólo es importante porque elude la pregunta acerca de las variaciones históricas del eje derecha-izquierda (aun cuando Downs, cabe reconocerlo, se propone dar cuenta de eventuales variaciones de los electores en relación a las categorías del eje, pero en un plano netamente espacial), sino porque además niega la posibilidad de variaciones sociales de los significados que distintos individuos atribuyen al eje y sus categorías. Es esta misma omisión la que se reitera en el influyente trabajo de Magar, Rosenblum y Samuels (1998), al intentar responder la pregunta de si el sistema binominal chileno promueve o no la competencia centrípeta. Es así como, a partir de un sofisticado modelo espacial a menudo fundado en supuestos irrealistas — como por ejemplo que "los votantes nunca se abstienen" (p. 721) — , los autores concluyen en la inexistencia de "un equilibrio centrista” comparable a un equilibrio de Nash, creyendo encontrar algún fundamento histórico según el cual "los candidatos de la lista L [izquierda] pueden escoger cualquier posición desde el medio (median) hacia la izquier$\mathrm{da}$, mientras que los candidatos de $\mathrm{R}$ [derecha] pueden escoger cualquier posición desde el medio hacia la derecha” (p. 721). El fundamento histórico de este supuesto estaría dado por el hecho de que "un candidato derechista (izquierdista) que intenta adoptar una posición izquierdista (derechista)" arriesga perder "el apoyo de los votantes de ambos lados del espectro" (p. 723), presumiendo que las posiciones del eje no admiten usos estratégicos, al concebirlas como esencias inmutables.

En tal sentido, resulta ser una importante contribución a las potencialidades de un modelo espacial la que hace Dow a propósito de la elección senatorial chilena de 1989, al asignarle explícitamente como límite a esta clase de modelización la cuestión de las variaciones geográficas del significado del eje derecha-izquierda en el electorado, puesto que "el significado

${ }^{4}$ Un supuesto que también se encuentra en Downs, aunque de modo menos radical, al postular que "los descontentos y los neutrales cuasi-informados se abstienen" (Downs, 1957, p. 85). 
político de ser un centrista en Valparaíso-Viña del Mar, por ejemplo, puede ser considerablemente diferente de lo que significa ser un centrista en los distritos de Santiago o de la VI Región, y es imposible descifrar estas diferencias solamente desde los mapas” (Dow, 1998, p. 463). Así, este franco reconocimiento de lo que una modelización espacial puede proporcionar y no lograr, constituye una elogiable lección de método, la que se encuentra completamente ausente cuando Colomer pretende modelizar la historia de la universalización del sufragio a escala latinoamericana, contrastando distintos casos nacionales mediante la caracterización de la importancia del tipo de "ganadores" producido por la relación variable entre ampliación del sufragio y crisis de régimen (Colomer, 2004a; para una severa y pertinente crítica de este trabajo, cf. Valenzuela, 2004, y la consiguiente réplica de Colomer, 2004b).

Esta misma eliminación de la historia de algunas categorías políticas también se observa a propósito de algunos de los objetos que son clásicamente estudiados en ciencia política, como por ejemplo los partidos políticos. Es así como es posible detectar una gran ambigüedad en el modo de interrogar algunos partidos políticos individuales en el presente, especialmente cuando la estrategia de investigación adoptada supone establecer filiaciones con organizaciones partidarias anteriores. Tal es el caso de los partidos de la derecha chilena, Renovación Nacional (RN) y la Unión Demócrata Independiente (UDI), dos fuerzas nuevas desde el punto de vista de sus etiquetas, ya que ambas siglas se encontraban ausentes en 1973. En tal sentido, resulta a lo menos aventurado afirmar que "hoy día, el partido más antiguo de la derecha es Renovación, el que ha existido desde 1966, pero que tiene su actual nombre sólo desde la transición a la democracia” (Montes, Mainwaring y Ortega, 2000, p. 804) ${ }^{5}$, por dos razones.

La primera radica en una filiación supuestamente directa entre el antiguo Partido Nacional y lo que los autores creen ver en Renovación Nacional 30 años después de la fundación del primero. ¿En qué consiste esta filiación? ¿En la difusión de ideas e ideologías políticas entre puntos distantes del tiempo? ¿En la continuidad de las mismas élites políticas entre uno y otro partido? ¿En idénticos, o si se quiere semejantes modos organizacionales de funcionamiento partidario? Estas son sólo algunas de las preguntas que es posible formular a propósito de afirmaciones referidas al nacimiento de partidos políticos individuales. Más profundamente, tras las afirmacio-

${ }^{5}$ Una afirmación que también se encuentra en el artículo de Barozet y Aubry, quienes afirman sin más "que existe una filiación directa entre el PN [Partido Nacional] y RN” (Barozet y Aubry, 2005, p.172, nota 21), lo cual podría ser una buena pista de investigación a condición de hacer la demostración de la aserción. 
nes de continuidad o permanencia de un partido político particular, lo que los autores eluden es el análisis genealógico de un partido como Renovación Nacional, el que se vuelve tanto más necesario cuanto más la respuesta a la pregunta referida al nacimiento del partido hace caso omiso de todo lo que implica una transformación de la denominación. Como bien lo señala Offerlé (1987), un partido es ante todo "una marca colectiva" de la cual se autorizan sus dirigentes y representantes (p. 19), y cuyo uso no será el mismo si esta marca ha variado a lo largo del tiempo. Si bien es posible sostener que un partido, no obstante haber experimentado mutaciones en su denominación, puede perfectamente heredar profundas continuidades a décadas de distancia (por ejemplo a causa del duradero impacto de la huella fundacional que Panebianco aborda a través de la hipótesis de la marca indeleble dejada por el "modelo originario": Panebianco, 1990), ello exige una demostración, sobre todo cuando la economía del trabajo genealógico permite asentar permanencias a partir de las cuales se infieren conclusiones generales acerca de una "limitada penetración partidaria en la sociedad" (Montes, Mainwaring y Ortega, 2000, p. 804). Independientemente del registro, objetivamente indiscutible, que estos autores hacen del número de etiquetas partidarias que compitieron en elecciones legislativas en Chile entre 1932 y 1997 (p. 71), ello no habilita a sacar conclusiones drásticas a partir de la simple constatación numérica de la "enorme rotación de los nombres de partido” (p. 804). ¿Resultan comparables los partidos que presentaron candidaturas tan sólo en una o dos elecciones con aquellos que lo han hecho durante décadas? Esta rotación nominal de etiquetas, ¿constituye evidencia suficiente para asentar juicios acerca de lo que los autores llaman una "débil penetración partidaria en el electorado” (p. 805), cuando al mismo tiempo es posible argüir que cuatro de los seis partidos que alcanzan alrededor del 95\% de los votos desde 1989 exhiben varias décadas de existencia electoral, aunque no siempre coronadas por la conquista de un escaño? ${ }^{6}$ Pueden entonces entenderse las implicancias, excesivamente vastas, del juicio genealógico que los autores hacen de Renovación Nacional, puesto que no es lo mismo decir que se trata de un partido cuyo origen se remonta a 1966, que iniciar su historia política y electoral en 1987.

Pero existe una segunda razón de por qué es aventurado establecer una filiación entre el antiguo Partido Nacional y Renovación Nacional. Contrariamente a lo que Montes, Mainwaring y Ortega (2000) piensan, la etiqueta RN no se origina en "la transición a la democracia” (p. 804), sino antes,

${ }^{6}$ Nos referimos al Partido Demócrata Cristiano (PDC), al Partido Socialista (PS), al Partido Radical Social Demócrata (PRSD) y al Partido Comunista (PC), aunque en este último caso sin éxito en escaños. 
concretamente en 1987. Esta fecha está muy lejos de ser anodina, puesto que cuando RN se forma y se oficializa como tal, es en un período previo a lo que la mayor parte de la literatura identifica como transición a la democracia. Pero por sobre todas las cosas, RN se forma en 1987 a partir de la reunión en su seno de un sinnúmero de fuerzas políticas de derecha, una de las cuales, la UDI, terminará siendo al poco tiempo un partido con élites y fuerza electoral propias. Así, más allá de la permanencia de la misma sigla entre 1987 y 1990, ¿es posible hablar de RN como si fuese el mismo partido a lo largo de tan sólo tres años? Claramente no, puesto que los usos de la sigla y los significados de los cuales ésta es portadora son muy distintos en 1987, en 1990 y a fortiori en los años posteriores, especialmente a partir del momento en que RN deja de ser el principal partido opositor, el 2001, en beneficio de la UDI. Lo que se debe rescatar de estas observaciones críticas respecto de las filiaciones y paternidades atribuidas a los partidos políticos, es la necesidad de hacer prueba de vigilancia metodológica acerca de lo que se juega en las cronologías y genealogías partidarias, sobre todo cuando éstas permiten asentar conclusiones con importantes consecuencias e implicancias, como es el caso en Montes, Mainwaring y Ortega (2000). En efecto, atribuir filiaciones más o menos largas o, peor aún, fechas de nacimiento a tal o cual partido político puede perfectamente redundar en un tipo de trabajo histórico "que a menudo consiste en ratificar y avalar 'hechos objetivos’ a costa de aplazar la investigación en el tiempo para mejor señalar los arcaísmos antecedentes", lo que equivale a decir que "no existe un punto de partida absoluto” (Offerlé, 1987, p. 35).

Esta misma crítica puede vertirse sobre los orígenes de la UDI, el principal partido chileno desde el 2001. Si bien es casi un lugar común retrotraer el momento de "nacimiento" de la UDI a 1983, fecha en la cual la sigla es inventada con el fin de nombrar a un "movimiento" que se desplaza desde las universidades católicas (especialmente la Pontificia Universidad Católica de Chile) hacia territorios populares, este año está muy lejos de ser una fecha de nacimiento evidente. ¿No constituirá una “mejor” fecha el año 1987, momento a partir del cual la sigla se vuelve cada vez más maciza (una vez que la fisonomía única de la derecha en torno a Renovación Nacional desemboca en una escisión y en la constitución de sedes, emblemas, tradiciones y una historia particular), masiva (con la paulatina constitución de un electorado proclive a la UDI) y valorada (al punto que después de las elecciones legislativas del 2001 surge la figura de una mascota de la UDI, udilito $)^{7}$ ? En tal sentido, una parte de la respuesta a la pregunta de cuándo se origina un partido reside en la presencia de lo que Bourdieu (1982) llamó

\footnotetext{
${ }^{7}$ Al respecto, cf. Joignant y Navia (2003).
} 
“actos de institución”, concebidos como momentos oficiales, y eventualmente solemnes de constitución de una línea divisoria entre un antes y un después, sean estos congresos, escisiones o eventos colectivos constituyentes. Pero la importancia de estos actos de institución no se reduce sólo a los aspectos de oficialización y constitución. Estos actos son también “operaciones mediante las cuales los grupos, al trazar fronteras y al dotarse de signos distintivos (especialmente la marca), concuerdan en reconocerse como grupo, a mostrarse como diferentes de los otros y a instituir un dentro y un afuera que son tanto más distintos cuanto más el partido se encuentra objetivado" (Offerlé, 1987, p. 35, subrayado por el autor). Se explica, entonces, que la UDI, al igual que RN, definitivamente no sean los mismos partidos en distintos momentos del tiempo, al admitir diferentes usos y significados asociados a cada una de las siglas dependiendo de las fechas de nacimiento que son solicitadas o avaladas por el investigador, de si forman o no parte de una misma organización, o si las hegemonías electorales recíprocas varían en el tiempo, confiriendo mayor o menor valor a una u otra de las siglas.

Estos son tan sólo algunos de los supuestos y premisas que es posible poner en evidencia por la vía de la deconstrucción de categorías de uso común en la literatura especializada sobre comportamiento electoral y sistemas de partidos en Chile. Pero más profundamente, un enfoque de sociología política que hace suya la empresa de deconstrucción no puede obviar el análisis más sistemático de la manera de cómo son abordados los cuatro grandes objetos de investigación que es posible identificar en la literatura, esto es: I) Las propiedades y efectos que son atribuidos al sistema binominal; II) El cambio o continuidad del sistema de partidos desde la perspectiva de la teoría de los clivajes; III) La unidad de análisis: ¿partidos o coaliciones?; IV) Los principios de explicación del voto de los chilenos.

\section{Efectos mecánicos y propiedades del binominal: incentivos teóricos, consecuencias supuestas y votante medio}

Gran parte de la investigación política sobre Chile se ha centrado en su sistema electoral binominal, cuyas propiedades formales son: una misma magnitud distrital ( $\mathrm{M}=2)$ en todos los distritos diputacionales y circunscripciones senatoriales; un modo de conversión de votos en escaños de acuerdo con la conocida fórmula d'Hondt; un sistema de lista abierta. Así definido, y a la luz de los resultados arrojados por cinco elecciones legislativas, se constata una regular distribución de los votos entre las dos principales 
coaliciones (por una parte la Concertación, y por la otra lo que hoy se conoce como la Alianza por Chile al cabo de varias refundaciones de esta alianza de partidos de derecha), las que acaparan alrededor del $90 \%$ de los sufragios válidamente emitidos en cada comicio. En cuanto a su funcionamiento, se trata de un sistema que hace sumamente difícil que una lista obtenga los dos escaños en disputa a nivel distrital o de circunscripción, puesto que para lograrlo requiere sacar el doble de los votos de la lista que la antecede inmediatamente. Hasta aquí no existen disensos, puesto que se trata de propiedades formales que como tales mapean la aproximación del investigador, del mismo modo que la constatada distribución de los sufragios y su consiguiente conversión en escaños no permite albergar dudas acerca de las lógicas de conformación de mayorías en ambas cámaras. Sin embargo, las discrepancias se vuelven notorias en tres aspectos. En primer lugar, respecto de la pregunta referida al impacto del sistema binominal sobre la formación de coaliciones. En segundo lugar, el funcionamiento del sistema binominal permite formular la pregunta acerca de sus efectos sobre el tipo de competencia que éste induce, esto es, si las elecciones legislativas son productoras de un juego político "centrípeto" o "centrífugo". Finalmente, como consecuencia de lo anterior, buena parte de la controversia científica se ha centrado en el dilema de cómo interpretar los resultados electorales que este sistema hipotéticamente encauza de acuerdo con el papel funcional que cumplen las ofertas de candidaturas y los comportamientos de los votantes que se localizan en posiciones espacialmente centrales: es la cuestión del "votante medio".

Hasta 1993, tendía efectivamente a prevalecer en la literatura la postura que ponía el acento en el efecto centrípeto de la competencia política que era supuestamente generado por el sistema electoral binominal, lo que era tácitamente reconocido por los autores críticos de este sistema al destacar más bien los fenómenos de exclusión de terceras fuerzas. Este énfasis en los benéficos efectos centrípetos del sistema binominal se aprecia claramente en los trabajos de Guzmán (1993), y sobre todo de Rabkin (1996). Si bien en ambos casos la postura acerca del carácter centrípeto que adquiere el juego político es tributaria de lo que los autores creen constatar sobre la base de una (Guzmán) o dos elecciones legislativas (1989 y 1993)², Rabkin sostiene sin embargo que en las elecciones de 1993 no se aprecia una desproporcionalidad particularmente grave entre votos y escaños de la Concer-

${ }^{8}$ A lo cual cabría agregar el clima general de "consensos" que regía en aquel entonces como consecuencia de lo que se conoció como la "política de los acuerdos": para un análisis de esta clase particular de política, cf. Joignant y Menéndez-Carrión (1999). 
tación y de la coalición opositora desde la perspectiva de los "estándares internacionales", y concluye que "raramente ocurre" una competencia "caníbal" al interior de las listas (Rabkin, 1996, p. 346). Dicho en otras palabras, el "sistema electoral binominal suscita competencia política centrípeta", lo que "ha contribuido a la estabilidad democrática en Chile" (p. 353). No parece discutible la afirmación de Rabkin en cuanto a la desproporcionalidad entre votos y escaños que el binominal arroja, especialmente si se le compara con sistemas mayoritarios uninominales a una sola vuelta (como el inglés), aun cuando resultaría más pertinente establecer comparaciones con sistemas proporcionales con lista abierta y bajas magnitudes distritales. Sin embargo, la afirmación referida al carácter centrípeto que adquiere el juego político gracias al binominal es muy controversial. En primer lugar, porque aun cuando el autor no se equivocase al constatar que los candidatos prefieren "hacer campaña de modo cooperativo con el compañero de lista en contra de la lista contraria” (Rabkin, 1996, p. 346), es probable que esta apreciación sea tributaria de la particular coyuntura electoral de 1993, caracterizada por una parte por la simultaneidad de los comicios presidenciales y parlamentarios, y por la otra por el carácter no competitivo de la elección presidencial, no sólo porque el resultado final refrendaría ex post esta aserción ${ }^{9}$, sino porque la propia negociación ex ante de la lista parlamentaria de la Concertación tomaba en consideración lo que sería el posterior resultado de la elección presidencial, a partir del supuesto de que el candidato presidencial que era percibido como favorito permitiría expandir el electorado de la Concertación, mejorando la performance parlamentaria de la coalición de gobierno ${ }^{10}$. En tal sentido, de ser cierta esta aserción a propósito de la Concertación, cabría preguntarse si también lo era para la oposición de derecha en aquel entonces, cuya hipótesis electoral no consistía tanto en doblar como en evitar doblajes en su contra ${ }^{11}$, lo que podría redundar en estrategias cooperativas entre los dos candidatos en los distritos que implicaban una amenaza, pero no en aquellos en donde la probabilidad de alcanzar un escaño era alta para ambas listas, volviendo verosímil una lucha al interior de cada lista por el único escaño que era razonablemente conquistable. En segundo lugar, y sobre todo, porque lo que se aprecia en Rabkin es

${ }^{9}$ En las elecciones presidenciales de 1993, el candidato de la Concertación Eduardo Frei obtuvo el 57,98\% de los votos, contra un 24,41\% del aspirante de derecha Arturo Alessandri Bessa, el resto de la votación distribuyéndose entre tres candidatos de izquierda y un candidato de derecha.

${ }^{10}$ Este supuesto, conviene señalarlo, será posteriormente ratificado por la literatura científica, una vez que tuvieran lugar dos elecciones legislativas (en 1997 y 2001) que no coincidían con la elección presidencial.

${ }^{11}$ Finalmente fueron 10. 
una confusión entre propiedades formales y efectos mecánicos del sistema binominal, y las variaciones históricas a las que se encuentra sujeto el éxito o fracaso de tal o cual lista en este tipo de sistema electoral. Si el rendimiento electoral de cada lista en competencia varía de acuerdo con las características históricas de las coyunturas eleccionarias, entonces cabría ser más precavido respecto de los efectos centrípetos que son atribuidos al sistema binominal, para lo cual se requeriría trabajar sobre una mayor cantidad de elecciones con el fin de detectar patrones, regularidades e inflexiones, por ejemplo distinguiendo entre comicios concurrentes o no concurrentes ${ }^{12} \mathrm{o}$ problematizando la conformación de listas en función de la eficacia relativa de políticas de seguros que se tornan más o menos viables dependiendo de la mayor o menor certeza de conquistar la primera magistratura ${ }^{13}$. De este modo, resulta problemático inferir dinámicas cooperativas que serían únicamente imputables a las propiedades constantes del binominal, y sumamente discutible concluir que este sistema ha contribuido per se "a la estabilidad democrática en Chile” (Rabkin, 1996, p. 353).

En contraposición con esta postura que insiste en atribuir efectos centrípetos al sistema binominal, lo que predomina hoy en día en la literatura es un juicio más bien crítico, aunque no siempre movilizando los mismos argumentos. Si bien buena parte de la literatura asienta un juicio crítico respecto de los efectos “centrífugos” del binominal por la vía de constituir en unidad privilegiada de análisis a las coaliciones en desmedro de los partidos individuales (un aspecto que abordaremos más adelante), conviene detenerse en los trabajos que dotan al "votante medio" (median voter) de la capacidad de producir consecuencias sobre el conjunto del juego político. Como es sabido, es a Downs (1957) a quien se le debe reconocer el mérito de haber puesto en evidencia la importancia de un electorado que, enfrentado a una oferta electoral fundamentalmente basada en cuestiones (issues) en torno a las cuales existen consensos básicos, emite preferencias sobre las mismas en términos equivalentes. En tal sentido, el supuesto restrictivo del modelo de Downs es la existencia de un conjunto de políticas respecto de las cuales la oferta de los partidos no puede desviarse ni alejarse, lo que explica la tendencia a la convergencia de lo que cada competidor ofrece sobre ciertos asuntos, presumiendo que la mayoría de los votantes (el votante medio) actuarán del mismo modo. Se entiende entonces que la importancia de esta oferta se traduzca en una localización de las cuestiones (is-

${ }^{12}$ Una pista que posteriormente será seguida por Cabezas y Navia (2005).

${ }^{13} \mathrm{Al}$ respecto, los trabajos de Siavelis (2005a) y de Carey y Siavelis (2005) son de real interés, en la medida en que logran poner en evidencia este tipo de políticas a propósito de la Concertación. 
sues) en la región central de un eje, o de un espacio n-dimensional, en torno a la cual convergen tanto la oferta de los partidos como las preferencias de los votantes. Es así como, según Paramio, la importancia del votante medio derivaría "de que si no existe esta convergencia carece de base la propia teoría democrática”, en la medida en que podría significar que una determinada mayoría no se originaría "sustancialmente [en] las preferencias de los electores” (Paramio, 2000). Positivamente entonces, el votante medio se erigiría en hipótesis "realista" (Paramio, 2000), generalmente corroborada por las elecciones que hacen los votantes. Si bien el modelo de Downs fue originalmente formulado en el marco de sistemas electorales de $\mathrm{M}=1$, la teoría del votante medio ha sido recurrentemente solicitada por la investigación sobre las elecciones legislativas chilenas (y no sólo presidenciales) con el fin de verificar la hipótesis de un efecto centralizador o centrípeto atribuible al sistema binominal. Más precisamente, el interés del modelo de Downs para las elecciones legislativas chilenas proviene de aquella situación, cuyos parámetros son descritos por el propio autor en un escenario coalicional, en donde sus "partidos periféricos" son proclives a "sentir que pueden ganar más votos moviéndose fuera del centro en lugar de moverse hacia él": así, una fuerza centrífuga "viene del deseo de todos los partidos en la coalición de maximizar las chances de que el conjunto de la coalición sea reelecta", lo cual, de verificarse, se logra "divergiendo ideológicamente de modo deliberado los unos de los otros", provocando "desintegración y haciendo difícil la coordinación” (Downs, 1957, p. 158). No cabe duda que es este último aspecto el que ha sido recogido por la literatura que se interesa en la caracterización de los efectos (centrípetos o centrífugos) producidos por el sistema binominal chileno, a veces sobre la base de formulaciones que carecen de fundamentación teórica y empírica ${ }^{14}$, y más a menudo a partir de adaptaciones y supuestos relativamente restrictivos.

Es en este segundo grupo de investigaciones, de lejos el más interesante, en donde cabe situar al influyente estudio de Magar, Rosenblum y Samuels (1998). El supuesto de partida de estos autores es que las propiedades del sistema binominal (el método d'Hondt y el voto de lista abierta) crean un verdadero dilema para los candidatos, el que denominan un "Juego de Socios Rivales” (Rival Partners Game) (p. 718). Así formalizado, este dilema no es la consecuencia causal, ni menos mecánica, del sistema binominal, sino más bien es una función de las expectativas de éxito relativo que

${ }^{14}$ Por ejemplo cuando se afirma sin más, respecto de una hipotética segunda ronda presidencial, que "la elección por mayoría en la segunda vuelta impediría elegir al candidato que se ubicara más lejos del centro del espectro político” (Payne, Zovatto, Carrillo y Allamand, 2003, p. 76) 
los dos candidatos de una misma lista asumen. Con el fin de representar las estrategias de los candidatos en distritos binominales, los autores emplean un modelo espacial que transforma el juego político en "un espacio político unidimensional”, en donde los votantes, los candidatos y sus ofertas son mapeados como puntos individuales a lo largo de este espacio. Así concebidos, los autores no se equivocan al señalar que los electores no son votantes propiamente tales, sino "puntos políticos ideales" (p. 719) cuya localización en el espacio es también de naturaleza ideal. Por consiguiente, varios de los supuestos que sustentan el modelo cumplen la función de justificar el trabajo de localización ideal de los candidatos y votantes en este espacio unidimensional, presumiendo que los candidatos de izquierda no pueden franquear la posición mediana, como tampoco lo pueden hacer los candidatos de derecha (p. 721). Si bien no parece útil el supuesto, irrealista, según el cual los votantes nunca se abstienen (p. 721), es interesante detenerse en aquel otro supuesto, sumamente restrictivo, de acuerdo con el cual la posición mediana o central actuaría como dique destinado a evitar la ruptura de la bella organización del espacio político. Los autores justifican este supuesto argumentando que, de no existir, "el juego no posee fin" (p. 722), lo que significa que ningún tipo de equilibrio podría emerger. Sin embargo, al inspirarse en la teoría de juegos, tal decisión de método obliga a los autores a volver soluble un dilema electoral de esta naturaleza, imputando la solución no a la soberanía del investigador, sino más bien a la racionalidad de los candidatos, quienes estarán siempre en relación de equivalencia con una fracción más o menos importante de los electores. De este modo, los autores concluyen que los candidatos al interior de cada lista, precisamente porque son agentes racionales, no buscan aproximarse a la posición mediana, sino todo lo contrario, con lo cual "no existe un equilibrio centrista” (p. 722) en el juego político chileno enmarcado por el sistema binominal.

Partamos por reconocer una primera infracción al modelo de Downs, esto es, candidatos, ofertas y votantes efectivamente puestos en una relación simétrica, pero a lo largo de un espacio unidimensional, muy distinto de aquel otro espacio propiamente downsiano de naturaleza n-dimensional. Si bien esta infracción no parece ser formalmente decisiva (aun cuando el reduccionismo es evidente al suponer que la competencia política se ordena en torno a una de las posiciones polares concebibles en Chile: izquierda / derecha, Sí / NO —en el plebiscito de 1988—, gobierno / oposición, etc.), ello deja de ser cierto cuando se interroga la importancia y el alcance de la posición mediana, cuyo impacto sobre la dinámica general del juego se presenta como excesiva al no admitir otras dimensiones. Aun más. La impecabilidad formal del modelo espacial que es formulado por Magar, Rosen- 
blum y Samuels (1998) se logra al precio del irrealismo, en la medida en que la posición mediana adquiere tácitamente una fisonomía de dique más material que espacial, al presumir que los candidatos y votantes de izquierda (puestos en relación de simetría) no pueden franquear la región central del espacio. En efecto, éste es un supuesto que teórica o idealmente puede ser verosímil, pero que sin discriminar entre los atributos políticos y hasta biográficos de los candidatos individuales a nivel distrital, redunda en una representación no sólo irrealista, sino que inexacta de las ofertas electorales y de las elecciones de los votantes. El supuesto, presuntamente refrendado en términos históricos, según el cual "un candidato derechista (izquierdista) que intenta adoptar una posición izquierdista (derechista) arriesga con perder" al final del camino el apoyo del electorado de ambos lados del espectro (p. 723), no permite explicar el éxito de candidatos individuales a nivel distrital cuyo discurso y, eventualmente, trayectoria biográfica, los habilita a cruzar el umbral de la medianía espacial sin tener que pagar costos electorales, lo que se verifica en la conquista de un escaño en distritos en donde la obtención de ambas bancas era improbable. Más allá de que se trate de una pista de investigación que requiere ser sometida a verificación empírica, todo indica que la demostración del carácter centrífugo del juego político que es suscitado por el sistema binominal según los autores adolece de la ilusión teórica, al no distinguir entre las representaciones ideales que se desprenden del modelo espacial y sus manifestaciones locales, o si se quiere distritales. Si esta ilusión es posible, ello se debe a que las posiciones adyacentes a la región central son concebidas como naturales, verdaderas esencias que serían profundamente internalizadas tanto por los candidatos como por los votantes de un dilema electoral, o si se quiere como una oferta natural formada por candidatos que encontraría una demanda equivalente hecha de electores.

De lo anterior no se puede inferir un desmentido de la dinámica centrífuga que el juego político adquiere en el marco organizado por el sistema binominal. Simplemente, la deconstrucción de los supuestos sobre los que descansa el trabajo de Magar, Rosenblum y Samuels (1998) pretende poner en evidencia el precio, cargado de irrealismo, que hay que pagar en aras de una demostración espacial. En tal sentido, el análisis de Dow (1998) sobre cuatro elecciones senatoriales chilenas realizadas en 1989, todas ellas regidas por la misma lógica formal del sistema binominal ${ }^{15}$, tiene la ventaja de apoyarse en datos perceptivos, fruto de encuestas que recogie-

${ }^{15}$ Con la sola diferencia de que el Senado se renueva por mitades cada cuatro años, en circunscripciones con poblaciones electorales generalmente mayores que los distritos diputacionales. 
ron la "opinión” de alrededor de 600 personas en cada circunscripción. Al igual que Magar, Rosenblum y Samuels (1998), Dow ensaya mapas espaciales a escala de cada una de las circunscripciones, interrogando el autoposicionamiento de los encuestados en una escala derecha-izquierda, el que es interpretado de acuerdo con información demográfica. Al respecto, Dow no encuentra asociaciones significativas entre variables demográficas y elecciones de los votantes una vez controlada la localización espacial estimada, lo que le permite al autor hipotetizar acerca del impacto del votante medio sobre las performances de los candidatos. Es así como el "análisis espacial empírico" de Dow demuestra que las "fuerzas centrífugas dominan las estrategias de los candidatos" (p. 467). Prueba de ello es que alrededor de la mitad de los candidatos que ganaron un escaño en las cuatro elecciones senatoriales estudiadas por el autor tendieron a localizarse en el "exterior del espacio" (p. 468), lejos del votante medio, lo que significa que los candidatos con más chances de alcanzar una banca son aquellos que son capaces de "diferenciarse" del "centro de la distribución de la opinión del votante” (p. 468). ¿Cómo explicarlo? Más que apelando a la imagen causal del imán cuya fuerza de atracción se debilita, Dow interpreta la escasa fuerza centralizadora del votante medio como consecuencia de los incentivos que un sistema d'Hondt en distritos binominales proporciona para alejarse de él. De este modo, haciendo gala de una gran elegancia, Dow no encuentra sustento alguno para afirmar que el sistema binominal produce un tipo de juego político centrípeto. El carácter convincente de su demostración proviene del hecho que ésta se sustenta en datos perceptivos, lo que reduce el riesgo de arbitrariedad y el espejismo de la ilusión teórica consistente en localizar a los candidatos y votantes en términos ideales a lo largo de un eje derecha-izquierda. Si bien su demostración es bastante contra-intuitiva respecto de la definición indígena de la competencia política que en aquel entonces predomina en el campo político ${ }^{16}$, el principal interés del trabajo de Dow reside en la introducción de una lógica realista de los incentivos. Serán estos incentivos, inscritos en las propiedades del sistema binominal, y no una fuerza de atracción más o menos inmanente del votante medio, los que determinan las estrategias de localización en el espacio político de los candidatos, produciendo así distancias y cercanías relativas respecto de la región central.

${ }^{16}$ Lo que se conoció como la democracia de los “acuerdos”, o de los “consensos”, lo que podría haber augurado un estrechamiento de la distancia ideológica entre las dos coaliciones principales, y la consiguiente convergencia en la región central del espacio político. 
Es contra una concepción mecánica de los incentivos que se inscriben en el sistema binominal, la cual conduce a concebir su eficacia en términos “absolutos e inmutables” (Siavelis, 2005a, p. 57), que Siavelis propone una aproximación contextual de los mismos. Por “contexto”, Siavelis entiende las variaciones coyunturales a las que puede estar sujeta una elección legislativa, esto es, el carácter concurrente o no de estos comicios con una elección presidencial, las correlaciones de fuerza entre sub-pactos (en el caso de la Concertación) o partidos (en el caso de la oposición de derecha) y las expectativas de victoria o de derrota presidencial para cada coalición. Así entendida, la dimensión “contextual” de los incentivos que se inscriben en las propiedades del sistema binominal involucran tres aspectos de naturaleza distinta: un aspecto institucional (la concurrencia o no concurrencia de una elección presidencial), la historia electoral de los socios de cada pacto (con el fin de determinar la distancia electoral relativa entre sub-pactos y partidos aliados en función de los resultados legislativos previos) y las percepciones y expectativas de triunfo en una elección presidencial que coincide, precede o que es posterior a la realización de los comicios legislativos. Pero más importante que estos tres aspectos “contextuales” que participan de la dirección de los incentivos, o si se quiere de sus usos por parte de los miembros de una coalición (los que variarán en función del interés que será maximizado, ya sea el de la lista en su conjunto o el de los subpactos y partidos individuales), es la eficacia relativa de una política de seguros la que determinará, finalmente, qué tipo de interés será favorecido. En tal sentido, los incentivos “contextuales” que se derivan del sistema binominal son concebidos por Siavelis como una función de las expectativas de triunfo electoral en una elección presidencial, la que podrá ser concurrente o no, puesto que la viabilidad de una política de seguros será proporcional a las anticipaciones de triunfo o de derrota en los comicios por la primera magistratura. Dicho en otras palabras, las tres dimensiones que Siavelis identifica pueden ser concebidas como riesgos o amenazas, los que podrán ser más o menos compensados por una política de seguros cuya eficacia, claro está, varía de una elección a otra.

De lo anterior se desprende una aproximación mucho más realista de los incentivos, en la medida en que, lejos de atribuirle una eficacia intrínseca al sistema binominal cuyos efectos serían de antemano previsibles, éstos recaen finalmente en los usos que los actores hacen del sistema electoral en función de ciertas coordenadas que se inscriben en una determinada situación. Ciertamente, esta estrategia de análisis no quiere decir que lo que los actores hacen con los incentivos del sistema binominal quede sujeto a una suerte de libre albedrío, equivalente a una completa indeterminación del 
comportamiento colectivo de las coaliciones, sub-pactos y partidos. Si es posible destacar el carácter realista del enfoque de Siavelis, ello se debe a que la incidencia de los incentivos se ancla en la actividad de cálculo de los actores, de la cual dependerá el modo de construcción de las listas (formadas por duplas simétricamente fuertes o, al revés, al estar asimétricamente constituidas, dependiendo del cálculo que los distintos partidos hacen respecto de sus chances de éxito electoral). En tal sentido, la política de seguros que el autor identifica, al estar hecha de compensaciones mediante nominaciones en posiciones de confianza presidencial (ministerios, subsecretarías y embajadas) en caso de que los beneficiarios hayan realizado contribuciones significativas al éxito de la coalición más que del partido, constituye un dispositivo de coordinación de intereses que, de no existir, desembocaría a la vez en una tendencia a la implosión de las alianzas y en un juego político de naturaleza centrífuga. Es precisamente a esta última conclusión a la que llegan Carey y Siavelis (2005), al destacar que la eficacia de la política de seguros destinada a premiar a los "buenos perdedores" (good losers) varía profundamente de una elección a otra, en función de los aspectos institucionales y electorales previamente señalados.

Sin embargo, una vez que los términos de la política de seguros se encuentran asentados en buena lógica realista, éstos tienden a perder de su verosimilitud a partir del momento en que son formalizados. En efecto, las variaciones de la eficacia de la política de seguros sobre la que se anclan los incentivos del sistema binominal son sometidas a un fuerte reduccionismo por parte de Siavelis, al fijar arbitrariamente umbrales de equilibrio o de desequilibrio electoral entre los sub-pactos o partidos que conforman cada lista. Es así como no se entiende ni justifica la formalización del "mapa de incentivos" que Siavelis (2005a, p. 76) elabora, al estar fundada en un umbral del $10 \%$ de votos y escaños de diferencia entre aliados para juzgar acerca del carácter fuerte de la lista finalmente formada, un poderío que declina hacia niveles intermedios cuando las diferencias en votos $o$ en escaños son superiores a 10\%, y que desemboca en listas débiles cuando este mismo umbral es superado en bancas y en sufragios. Si lo que se busca es proporcionar una explicación de la manera de cómo los incentivos inciden en el carácter más o menos fácil de las negociaciones conducentes a la formación de las listas con el fin de fundamentar el carácter centrífugo del juego político, entonces el umbral del 10\% recién señalado parece arbitrario. ¿Por qué situar el umbral en este porcentaje, y no en otro? ¿Es este mismo umbral el que es tomado como base de cálculo por los actores que concurren a negociar las listas electorales? Si los actores negociadores son tácita- 
mente asimilados a partidos y sub-pactos, ¿qué tipo de racionalidad prevalece en ellos al momento de negociar? ¿Hasta qué punto las preferencias de los actores negociadores, así como sus intereses, son susceptibles de variar? Si todos los actores poseen la misma información "contextual” al momento de negociar, ¿significa entonces que existe una relación de equivalencia entre la información previamente disponible y los resultados de la negociación? Buena parte de la explicación de los silencios que se asocian a cada una de estas preguntas proviene de un supuesto de racionalidad de los actores que da por sentada su materialización en el orden empírico de las cosas, con lo cual se pierde la dimensión realista de los incentivos del sistema binominal que había sido alcanzada al momento de formalizar el "contexto" histórico e institucional de la negociación de las listas.

El trabajo de formalización del objeto de estudio no necesariamente implica abandonar el realismo de las situaciones políticas con el fin de acceder a explicaciones verosímiles, pero irreales. En tal sentido, como bien lo señala Boudon a partir de una crítica a la teoría de la acción a la que adscriben las sociologías disposicionales, el conocimiento científico no puede ser satisfactorio mientras permanezcan en el objeto de estudio "cajas negras" cuya presencia hace imposible acceder a explicaciones "finales" (Boudon, 1997, p. 226). Una de esas cajas negras, sumamente importante, se refiere a lo que los actores hacen o no hacen con la información disponible, lo que supone dar cuenta de su comportamiento y del tipo de racionalidad que ellos siguen. El trabajo de Carey y Siavelis (2005) se propone precisamente abordar la pregunta del comportamiento de los actores, en este caso en desmedro de la caracterización del contexto de la acción, analizando la "distribución del riesgo" (p. 5) entre actores que concurren a formar una lista de dos candidatos en los distritos binominales chilenos. La política de seguros destinada a premiar a los "buenos perdedores" no opera, entre los partidos de la Concertación, como un "contrato escrito", sino como "un acuerdo informal sobre el que se basan las mutuas expectativas de los candidatos y de los líderes de la coalición” (p. 7). Como se puede apreciar, por primera vez se hace directamente referencia a los usos individuales del riesgo por parte de dos clases de actores (candidatos y líderes de la coalición), lo que se confirma a través de una metodología intuitiva empleada por Carey y Siavelis consistente en recoger corroboraciones de estos usos a través de "conversaciones con legisladores tanto al interior como al exterior de la Concertación" (p. 7). Si bien estos dos autores se interesan principalmente en la distribución del riesgo entre candidatos y dirigentes de la Concertación, sería interesante comprender en los mismos términos el tratamiento 
que los actores de derecha dan a los distritos binominales. En cualquier caso, esta distribución del riesgo es formalizada por los autores de acuerdo con los términos de una política de seguros que, a diferencia del estudio de Siavelis (2005a), se centra exclusivamente en una relación modelizada entre el componente de premiación (un nombramiento en una posición de confianza presidencial) y los requisitos electorales que permiten acceder a él (haber sido candidato a la Cámara de Diputados o al Senado, un ratio de coalición que se obtiene dividiendo el voto de la Concertación por el voto de la lista de derecha, y un ratio de la Concertación, que es el resultado de la división de los votos de la primera mayoría de la lista por los sufragios de su compañero de lista). De este modo, los autores concluyen que existe una probabilidad incremental en ser recompensado a través de una nominación presidencial cuando: se compitió por el Senado; se estuvo cerca de "doblar" a la derecha; y hubo una contribución relativamente equilibrada al voto total de la lista (aunque sobre este último criterio los autores cifran "menos confianza”) (p. 9). No cabe duda que esta estrategia de análisis les otorga mayor centralidad a los usos del riesgo por parte de actores que aceptan el reto de ser candidatos a partir de expectativas de éxito que no necesariamente se materializan en la conquista de un escaño. En tal sentido, se pueden entender mejor aquellas candidaturas sobre las cuales existen dudas razonables acerca de sus probabilidades de éxito electoral, incluso cuando la probabilidad de obtener una nominación presidencial es finalmente defraudada. Es por esta razón que es destacable el mérito del realismo de las decisiones individuales en el trabajo de Carey y Siavelis (2005), del mismo modo que en la contribución de Siavelis (2005a) en un "contexto" institucional y de historia electoral de estas mismas decisiones riesgosas.

Sin embargo, ¿significa esto que las decisiones individuales de presentarse como candidato se originan en una racionalidad (aquí formalizada) que sería asumida como tal por los actores involucrados? Ciertamente no, puesto que es posible hipotetizar que determinados actores toman la decisión de ser candidatos a partir de razones distintas a las que admite el modelo, como por ejemplo de disciplina partidaria, iniciación de una carrera política o simplemente por información imperfecta conducente a errores de cálculo. Es así como se podrían, por ejemplo, entender las candidaturas senatoriales de Germán Correa (PS) y de Camilo Escalona (PS) en 1997, o la de Aníbal Pérez (PPD) el 2005, todas ellas de éxito electoral improbable, las que por añadidura nunca fueron recompensadas por una política de seguros como la evidenciada por Carey y Siavelis. Es cierto que, en dos de ellas, la diferencia en votos fue de 12 y 23 puntos respectivamente en relación al 
compañero de lista ${ }^{17}$, con lo cual se comprendería que estos dos candidatos no hayan sido compensados al no ser "buenos perdedores", mientras que en el tercer ejemplo el candidato socialista Germán Correa obtuvo 8 puntos menos que su aliado de coalición Sergio Páez (PDC) ${ }^{18}$. En todos los casos, resultaba sumamente improbable que la Concertación duplicara en votos a la oposición de derecha, no obstante lo cual tres duplas fuertes - y asimétricas - se formaron sin que ninguno de los candidatos perdedores fuera recompensado. ¿Cómo explicarlo? Ciertamente no apelando a una interpretación ortodoxa de la política de seguros tal como es concebida por Carey y Siavelis, puesto que una aplicación estricta y políticamente ciega de este dispositivo compensatorio podría satisfacer las necesidades formales de la explicación, pero al precio fuerte de la inverosimilitud. En efecto, a menos de adherir a una lectura mecánica de la política de seguros, o a una concepción ingenua del suicidio electoral, estas tres candidaturas se originan en motivos y racionalidades que no son capturados por la lógica del modelo de Carey y Siavelis. No puede ser un dato anecdótico el constatar que tanto G. Correa como C. Escalona habían sido previamente presidentes del Partido Socialista, un elemento de biografía política que es obviado por el modelo de los autores y que podría participar de la explicación de sus respectivas candidaturas, ya sea apelando a decisiones fundadas en concepciones de lealtad, deber o disciplina partidarias, ya sea solicitando la hipótesis pocas veces investigada de errores de cálculo.

Estos silencios del modelo de Carey y Siavelis probablemente se explican por las restricciones formales de sus incentivos y compensaciones probables, y por tanto por una concepción estrecha de la racionalidad de los actores. Por consiguiente, por muy realista que pueda parecer la política de seguros que los autores analizan a partir del caso de la Concertación, este modelo de compensaciones e incentivos obliga a reformular la concepción de la racionalidad individual que se encuentra involucrada. Curiosamente, es nuevamente a Siavelis a quien se le debe reconocer el mérito de dar cuenta de la "lógica oculta" que predomina en el proceso de selección de candidatos de la Concertación, mediante entrevistas sostenidas con los dirigentes encargados de seleccionar a los postulantes y formar las listas en distritos binominales. Ciertamente, Siavelis no se equivoca al señalar que

${ }^{17}$ Andrés Zaldívar (PDC) obtuvo el 27,77\% de los votos contra un 15,98\% de Camilo Escalona (PS) en la circunscripción senatorial de Santiago Poniente en 1997, mientras que Juan Pablo Letelier (PS) alcanzó el 41,42\% de los sufragios contra un 19,45\% de Aníbal Pérez (PPD) en la circunscripción senatorial correspondiente a la VIa Región el 2005.

${ }^{18}$ Concretamente, Sergio Páez se impuso con el 28,43\% de los votos, secundado por Germán Correa con el 20,22\%. 
existe "algún grado de regularidad en la representación partidaria en el Congreso" (Siavelis, 2002b, p. 426), esto es, patrones de decisión a los que se apegan los negociadores de los partidos de la coalición. Sin embargo, en lugar de postular un apego estricto y presumiblemente "consciente" a regularidades que permiten explicar la elección de distritos y la consiguiente representación de los partidos en el Congreso, Siavelis prefiere tomar al pie de la letra el aforismo chileno "en el camino se arregla la carga" (p. 423), una suerte de modo de conocimiento y de aproximación a las negociaciones entre partidos que es mucho menos restrictiva que las concepciones de la racionalidad que predominan entre los teóricos de la elección racional y los partidarios de los modelos formales (como es el caso del propio Siavelis). En tal sentido, el aforismo señalado por Siavelis instala las condiciones de posibilidad de una racionalidad de naturaleza práctica, muy distinta de aquella otra racionalidad que interpreta las decisiones y elecciones de los actores en función de la maximización del propio interés, o en el mejor de los casos de su satisfacción ${ }^{19}$. De este modo, con el fin de circunscribir las negociaciones y posteriores decisiones de candidaturas de los dirigentes de la Concertación, Siavelis enumera cuatro grandes reglas generales, todas ellas derivadas de una lógica oculta que es rara vez explicitada por los actores, según la cual la totalidad del proceso se ordena en torno a un partido "ancla", una característica que se le atribuye al principal partido electoral de la coalición. Dicho en otras palabras, los partidos anclas poseen una primera opción para optar por una banca en listas binominales, aun cuando este partido pueda eventualmente ceder "un pequeño número de escaños a los socios menores” (p. 429). Las condiciones de negociación, entonces, son lo suficientemente generales para que los líderes de la Concertación apelen a un tipo de racionalidad que se expresa en elecciones prácticas.

Son infinitas las posibilidades de análisis que ofrece una sociología de la práctica que toma muy en serio el aforismo "en el camino se arregla la carga”. Desafortunadamente, Siavelis no las aprovecha completamente, al concederle más importancia a las reglas generales que él mismo explicita que a los comportamientos de los actores involucrados en el proceso de selección de candidatos. Si bien la decisión de concentrarse en la "lógica oculta" del proceso, cuyos parámetros son cuatro reglas generales, es legítima desde el punto de vista metodológico, no es posible sin embargo no hacer referencia a los usos prácticos de estas mismas reglas. En primer lugar, al

${ }^{19}$ Con lo cual aludimos por una parte a las concepciones de la racionalidad total, o completa, y por la otra a la muy influyente teoría de la racionalidad limitada que se desprende de la inmensa obra de Simon (1984). 
realizar entrevistas a dirigentes, Siavelis podría haber incursionado en las controversias para determinar las condiciones que un partido debe reunir para ser definido como partido ancla. Evidentemente, si el nivel de determinación de este atributo es el espacio electoral nacional, no cabrían dudas acerca de la identificación de dicho partido. Pero, ¿̇es realmente en este nivel que cabe asentar este atributo, y no a nivel distrital? ¿De qué modo puede ser aceptado el uno o el otro nivel de determinación? ¿Apelando únicamente a la objetividad de los resultados electorales previos? ¿Recurriendo a la presión o a la amenaza de no formar parte de la lista de la Concertación? ¿Y qué hay de aquel otro aforismo, político en este caso, según el cual quien dispone de un escaño tiene un mejor a derecho a presentar candidatos? En segundo lugar, no parece obvio identificar el partido ancla mejor rankeado después de reconocer cuál es el primero, ni menos dilucidar las razones de la primacía partidaria a nivel de sub-pactos, como se desprende de las reglas dos y tres de Siavelis (2002b, p. 429). En todos estos casos, y de modo congruente con el aforismo chileno solicitado por el autor, lo que se presenta como objeto de investigación es el universo de usos prácticos de estas cuatro reglas generales, explicitando las racionalidades a las que los dirigentes de la Concertación recurren con el fin de determinar el partido ancla de la Concertación y de sus sub-pactos. Nada prohíbe inferir de estas distintas racionalidades motivos de disputa entre aliados, susceptibles de traducirse en relaciones de fuerza en los espacios formales e informales de negociación. Aun más. En la medida en que Siavelis construye su objeto de estudio en los términos de un proceso que recoge la historia de las selecciones de candidaturas legislativas en los años 1989, 1993 y 1997, resulta posible hipotetizar acerca de la acumulación de conocimiento negociador por parte de los dirigentes de la Concertación, pudiendo eventualmente encontrarse en el origen de teorías electorales de corte práctico. En ese marco, la pregunta de investigación se desplazaría desde el enmarcamiento del proceso de selección de candidaturas por reglas generales, hacia los usos particulares de las mismas, tomando en consideración los aprendizajes previos y su consiguiente impacto en los comportamientos selectivos posteriores, lo que eventualmente se traduciría en teorías internalizadas por los actores con fines prácticos. De este modo, la investigación ganaría en realismo, al hacer de los actores localizados en un momento posterior del tiempo agentes depositarios de experiencias previas, las que se expresarían en estrategias, comportamientos y elecciones orientadas por lo que Bourdieu llamó un sentido práctico del problema (Joignant, 2000) o de la situación.

Puede entonces entenderse que la pregunta referida a los efectos del sistema binominal no se responda fácilmente. No sólo porque los efectos 
(centrípetos o centrífugos) no son el resultado mecánico de las propiedades formales del sistema electoral, sino porque éstos están determinados por los incentivos que éste admite y por el hipotético papel que desempeña el votante medio, a condición de concebir a este último más como una construcción que como una esencia, cuya objetividad orientaría las estrategias de los candidatos y las elecciones de los votantes... como si el votante medio fuese un aspecto estable del mundo político, duro como una roca y visible como un semáforo del tránsito electoral. La versión probablemente más extrema de esta concepción objetivista del votante medio se encuentra en Colomer (2004c), cuando este autor hace referencia tanto a un votante como a un "escaño mediano" (p. 155) a propósito de sus capturas sucesivas en la Alemania de la postguerra, al constatar en el caso de Inglaterra que desde 1906 ningún partido ha obtenido una mayoría absoluta de votos populares, lo que sería una prueba del carácter "relativamente extremo" del partido vencedor (p. 129). Aunque de modo menos radical, esta misma concepción objetivista y artefactual del votante medio se encuentra presente en la literatura sobre Chile, presuponiendo que el votante medio es espacialmente siempre el mismo, de valor e importancia constante, en completa indiferencia respecto de los usos del espacio político y de los incentivos del binominal por parte de los candidatos. Pero más profundamente, si la mayor parte de la literatura concluye, por distintas razones metodológicas, que el juego político adquiere una dinámica centrífuga, ello se debe no tanto a las bondades de los modelos (espaciales o formales) utilizados, como a los usos de los incentivos que los actores hacen en función de la información, de la experiencia o del conocimiento adquirido a lo largo del tiempo. En tal sentido, la pregunta de investigación que se impone es cómo son empleados estos incentivos, una interrogante que se responde fácilmente cuando la respuesta se encuentra inscrita en los términos de un modelo, y con mayor dificultad cuando ésta se pretende anclar en las racionalidades prácticas de los actores. En ese sentido, el juicio taxativo según el cual "el sistema binominal polariza moderadamente el sistema político" (FLACSO, 2006, p. 25), una suerte de diagnóstico mediano susceptible de satisfacer los intereses políticos de muchos actores, es definitivamente insuficiente, al presuponer una eficacia mecánica de los incentivos institucionales, eludiendo una vez más la pregunta referida a los usos políticos por parte de los dirigentes de coalición.

La discusión sobre los efectos del sistema binominal, necesariamente mediada por la lógica de sus incentivos y de los usos que hacen los actores, ha tendido a desbordar sobre otra pregunta: ¿de qué manera caracterizar el sistema de partidos? ¿Es el mismo sistema de antes del golpe de 
Estado de 1973, o es un sistema distinto? Los autores que destacan la emergencia de un juego político centrípeto, suelen inferir de esta observación una fuerte discontinuidad del sistema de partidos, mientras que otros, al relevar una dinámica más bien centrífuga, concluyen lo contrario. En ambos casos, sin embargo, el juicio acerca del cambio o de la continuidad del sistema de partidos se presenta como conclusión secundaria, en la medida en que la unidad de análisis es otra. Ello explica que un juicio referido a las características del sistema de partidos, a su permanencia o discontinuidad, exija que el objeto principal de análisis esté constituido por la trama de relaciones o interacciones regulares entre partidos a través de estrategias de investigación adaptadas a dicho objeto. Son estas estrategias, así como los juicios que éstas hacen posible emitir, las que serán abordadas en la siguiente sección.

\section{Los clivajes del sistema de partidos en Chile: entre la estabilidad de las etiquetas y la discontinuidad de las preferencias}

No parece equivocado señalar que la controversia más afincada en los estudios políticos sobre Chile se refiere a las características de su sistema de partidos. En efecto, a partir de diversas metodologías y sobre la base de distintas interpretaciones de los clivajes que hacen las veces de cimientos del sistema de partidos, la reflexión sobre las organizaciones partidarias y el sistema que se deriva de las relaciones regulares que éstas sostienen entre sí y con los electores, forma parte de una duradera controversia chilena. Para algunos autores, la observación del sistema de partidos en Chile permite sostener la tesis de continuidad de sus organizaciones, interrelaciones y de las preferencias electorales que lo sustentan, mientras que para otros el resultado de la observación permite asentar un juicio de discontinuidad. ¿Cómo dirimir la controversia? Sin duda, tomando en consideración cada una de las demostraciones, a condición de estar de acuerdo con lo que se entiende por "clivajes" y "sistema de partidos".

Como es bien sabido, un sistema de partidos surge y se consolida en función de ciertos clivajes que una sociedad nacional produce, entendiendo por "clivajes" (cleavages) fisuras o fallas de naturaleza estructural en torno a las cuales emergen fuerzas políticas que representan intereses originados por estos clivajes. Son estos clivajes, por consiguiente, los que explican la formación de los partidos, cuyas luchas a la vez recuerdan su propia génesis y configuran patrones regulares de competencia que se objetivan en los denominados sistemas de partidos. Así entendidos, los partidos políticos y 
los sistemas que ellos conforman no son el fruto de decisiones fundacionales tomadas en el más completo libre albedrío, sino que son el resultado de transformaciones complejas de la sociedad, las que engendran condiciones sociales de posibilidad para el surgimiento de fuerzas políticas organizadas. Es en el trabajo, clásico e influyente, de Lipset y Rokkan (1967) en donde se encuentran los fundamentos para comprender la formación de los sistemas de partidos. Trabajando a escala de Europa occidental, estos dos autores muestran que los partidos políticos europeos, así como los sistemas que ellos conforman, surgen a continuación de la irrupción de conflictos sociales que ningún actor particular originó, al ser el resultado de transformaciones de la propia sociedad, con lo cual la pregunta de los orígenes de los partidos admite respuestas más sociales que políticas. En efecto, los autores constatan que los sistemas de partidos modernos son el resultado de procesos sociales de "congelamiento", en cuyo perímetro se configuran "alineamientos corrientes de los votantes" (p. 3), dos aspectos de un mismo problema que se explican a la luz de la aparición de clivajes tales como la fisura secular / anti-secular, trabajadores / capitalistas o de una brecha social entre el espacio urbano y rural. En tal sentido, el análisis de un sistema de partidos requiere centrarse en los clivajes que lo originan, incluso admitiendo la posibilidad de coexistencia de varios clivajes (y por tanto, de varios partidos), lo que obliga al investigador a dotarse de los medios para "saber cuándo un tipo de clivaje sobresaldrá más que otro" (p. 6), con el fin de evidenciar "una jerarquía de las bases de clivaje en cada sistema” (p. 6). Ciertamente, Lipset y Rokkan no ignoran que la importancia y centralidad relativa de los clivajes difieren de un país a otro, del mismo modo que los sistemas de partidos, pero en ningún caso pierden de vista la génesis social de ambos. Es por esta razón que el enfoque de Lipset y Rokkan puede ser caracterizado como sociológico, al hacer prevalecer las condiciones sociales de emergencia de los sistemas de partidos en desmedro de eventuales condiciones políticas, de lo cual es prueba categórica la afirmación de que "en la mayoría de los casos hace poco sentido tratar a los sistemas electorales como variables independientes y a los sistemas de partidos como variables dependientes” (p. 20).

Si bien la teoría de los clivajes de Lipset y Rokkan admite dudas sobre la arquitectura polar de los sistemas de partidos que los clivajes producen, es sobre ella que buena parte de la literatura referida al sistema de partidos chileno se sustenta. Es así como una parte de la literatura concluye, a partir de una lectura ortodoxa del trabajo de Lipset y Rokkan, que el sistema de partidos se encuentra fundamentalmente regido por una lógica de continuidad, desde la permanencia de las etiquetas partidarias hasta la 
reproducción de sus respectivos electorados. Tal es el caso de Scully y Valenzuela (1993), y posteriormente de la influyente contribución de Valenzuela (1995), quienes infieren un "alto grado de continuidad" del sistema de partidos en Chile a partir de una notable permanencia de las orientaciones del electorado, mediante "correlaciones observadas entre los resultados electorales" a nivel de comunas “de 1988 y 1989, y los de 1969, 1970 y 1973" (Scully y Valenzuela, 1993, p. 198; para un análisis que extiende el estudio a nivel comunal hasta 1992, cf. Valenzuela, 1995). Si bien esta conclusión es alcanzada a través de una astucia metodológica, productora de resultados artefactuales, la cual consiste en hacer como si las coaliciones de partidos existentes en 1969, 1970 y 1973 fuesen aun electoralmente pertinentes en la década del 90, Scully y Valenzuela no cuestionan la naturaleza de los clivajes que originan tanto a los partidos políticos chilenos como al sistema que éstos conforman. Aun más. Al detectar, por la vía de la astucia metodológica, alineamientos electorales que sustentan las mismas correlaciones de fuerza en momentos distintos del tiempo (los famosos tres tercios electorales), los autores no vacilan en concluir en la persistencia tanto del sistema de partidos como de las preferencias electorales que lo sustentan.

El trabajo de Dow (1998) viene a refrendar este juicio de centralidad de las preferencias electorales, al encontrar evidencia específica, a través de una estrategia de análisis completamente distinta, sobre la permanencia del universo político constituido por el Partido Comunista y el Partido Socialista. Acudiendo a datos perceptivos, Dow sostiene que "los posicionamientos comunista y socialista" permiten afirmar que "los cambios en políticas y tácticas no son necesariamente reflejados en las percepciones políticas de las masas" al inicio de los periodos transicionales, poniendo así de manifiesto el "que los votantes perciben importantes continuidades con el universo político pre-autoritario" (Dow, 1998, p. 462). No obstante referirse únicamente a la permanencia de los "posicionamientos" comunista y socialista, Dow muestra de modo muy sugerente un aspecto inercial de estos dos electorados, esto es, conjuntos de votantes que no experimentan evoluciones congruentes con las transformaciones doctrinarias de los partidos, lo que no les impide sufragar por estos dos partidos, percibiendo continuidades fundamentales entre el presente democrático y el pasado pre-autoritario. El argumento de Dow es interesante, ya que aun constando cambios programáticos o ideológicos eventualmente muy profundos de los partidos, no se pueden inferir transformaciones equivalentes en los electorados de los partidos, quedando así en evidencia algo parecido a un desfase entre la oferta de los partidos y las preferencias de los electores, en el sentido en que el primer aspecto es la consecuencia de mutaciones propias de las 
fuerzas políticas, y el segundo el resultado de continuidades que se expresan en una orientación del voto que hace caso omiso de los cambios que afectan a la oferta política. Dow sugiere que este desfase se produce al inicio de los periodos transicionales, un supuesto que es cronológicamente congruente con la definición temporal de su objeto de estudio, esto es, cuatro elecciones senatoriales realizadas en 1989. ¿Significa esto que las preferencias del electorado comunista y socialista se adecuarán a los "cambios en las políticas y tácticas” del PC y del PS en momentos posteriores del tiempo? Es imposible responder esta pregunta en el marco del modelo espacial propuesto por Dow, al no trabajar sobre series de elecciones. Sin embargo, esto no le impide concluir, en los límites temporales del objeto estudiado, en una importante continuidad de quienes votan por estos dos partidos en relación con el periodo inmediatamente previo al golpe de Estado de 1973, basando su aserción en datos perceptivos recogidos a través de encuestas. Pese a todo, Dow instala una interesante pista de investigación para dar cuenta de la continuidad del sistema de partidos, asentando su juicio en la permanencia de las percepciones del electorado independientemente de las transformaciones de los partidos individuales. Esta pista podría ser explorada a partir de una hipótesis sociológica de Bourdieu, quien pudo explicar situaciones sociales de desfase apelando a la metáfora de Don Quijote, cuya lucha en contra de molinos de viento es la expresión de una continuidad esencial observable en las percepciones del mundo social y en los comportamientos que éstas admiten, en circunstancias que el mundo bélico así aludido había dejado de existir (Bourdieu, 1979). La clave de este verdadero enigma, que Bourdieu ilustra a través del ejemplo de los conflictos generacionales entre padres e hijos, reside en la permanencia de las experiencias y de los aprendizajes previos por parte de grupos sociales enteros, aun cuando las situaciones que hicieron posibles estas experiencias y aprendizajes hayan profundamente variado. Esta dimensión inercial de los sistemas de creencias de los individuos y grupos, sean estos generaciones, clases sociales o electorados, que Bourdieu denomina "efecto de hystérésis”, es mucho más usual y difundida que lo que el sentido común permite aceptar, y podría encontrarse en el origen de estrategias de análisis político y electoral más exigentes para dirimir la pregunta acerca de las supuestas continuidades o de presuntos cambios de los sistemas de partidos.

Desafortunadamente, la agenda de investigación sobre el sistema de partidos chileno sigue apegada a la teoría de los clivajes de Lipset y Rokkan, así como a un trabajo de medición destinado a detectar correlaciones con el fin de fundamentar juicios de continuidad o de discontinuidad. $\mathrm{Al}$ respecto, tras la duradera influencia ejercida por Scully y Valenzuela 
(1993), y especialmente por este último (1995), se aprecia un paulatino predominio de investigaciones que concluyen en una profunda transformación del sistema de partidos, no sólo debido al surgimiento de nuevos patrones de alianzas, sino sobre todo a causa de la emergencia de clivajes de nuevo tipo.

Es a Tironi y Agüero (1999) a quienes se les debe reconocer el mérito de haber reformulado la manera de analizar el sistema de partidos en Chile. Los autores comienzan por reconocer que el sistema de partidos chileno se originó en torno a "dos fisuras generativas", cada una de ellas constituidas por "polaridades": la primera, "en torno a la polaridad Estado v/s Iglesia”, y la segunda bajo el influjo de "la polaridad trabajadores v/s empresarios" (p. 153). La argumentación de Tironi y Agüero no apunta a invalidar la histórica incidencia de estos dos clivajes, sino a rebatir la tesis de Scully y Valenzuela según la cual el sistema de partidos chileno estaría dominado por una lógica de continuidad entre el periodo previo al golpe de Estado de 1973 y lo que se observa desde 1989 en adelante. Esto significa que, aun cuando las dos fisuras generativas puedan haber efectivamente existido en el pasado, no es posible sostener su "vigencia rectora" en la década del noventa. Por consiguiente, lo que Tironi y Agüero constatan es una fuerte “discontinuidad” del "paisaje político chileno" (p. 155), lo que exige una demostración no sólo del debilitamiento de los dos clivajes históricos, sino del surgimiento de nuevos clivajes. Es así como estos dos autores constatan una organización completamente distinta del sistema de partidos, al haber dado paso por una parte a "un sistema bipolar" que carece de centro y “cuya dinámica tiende a ser centrípeta” (p. 155), y por la otra a "un pluralismo des-polarizado o moderado" que permite la aparición de nuevos patrones de coalición, lo que se traduce en la formación de dos nuevas alianzas políticas que compiten "por los votos del centro" (p. 155). Según los autores, esta nueva organización del sistema de partidos se traduciría en una declinación de las “lealtades partidarias originales” (p. 158) y su sustitución por "una nueva fidelidad a las coaliciones" (p. 159).

Si bien el supuesto de los autores según el cual el "electorado de la Concertación" tiende a "elegir candidatos al interior de la coalición, con una relativa prescindencia del partido al que ellos están afiliados" (p. 158) dista mucho de corroborarse en la realidad, lo esencial de la argumentación gira en torno a la emergencia de nuevos clivajes. Más precisamente, Tironi y Agüero afirman que esta reorganización del sistema de partidos se oficializa con el plebiscito de 1988, un evento eleccionario que "marcó el fin del anterior paisaje político de los 'tres tercios”" (p. 155), al engendrar una nueva fisonomía que explicaría a la vez la conformación de dos grandes 
coaliciones y la orientación del comportamiento electoral de los votantes. De este modo, lo esencial de la argumentación de los autores reside en la emergencia de un nuevo clivaje, cuyo origen es más político que social, dotado de la capacidad de subordinar, y tal vez de desplazar el predominio de las dos grandes fisuras que dieron origen al sistema de partidos en Chile.

Como se puede constatar, existe una evidente diferencia en el uso de la teoría de los clivajes de Lipset y Rokkan por parte de estos dos autores. En efecto, mientras Lipset y Rokkan privilegian la génesis social de los clivajes sin desconocer completamente la posibilidad de surgimiento de fisuras como consecuencia de procesos o eventos políticos, Tironi y Agüero invierten la lógica genética de los clivajes, al formular la hipótesis de una reorganización del sistema de partidos en función de clivajes de naturaleza esencialmente política. Sin embargo, ¿son realmente comparables los clivajes que se originan en el marco de las dos grandes revoluciones analizadas por Lipset y Rokkan, esto es la "Revolución Nacional” que acompaña la construcción del Estado y su separación de la esfera espiritual, y la "Revolución Industrial” que da a luz a clases sociales enteras, y en ambos casos a líneas divisorias entre partidos políticos en pugna (Lipset y Rokkan, 1967, p. 34), con aquellas otras fisuras cuya génesis es más bien política, como por ejemplo el conflicto entre democracia y dictadura y su traducción electoral en un evento plebiscitario entre alternativas irreconciliables (el Sí y el NO en el plebiscito de 1988), la que posteriormente se reproduciría en elecciones generales (entre una coalición de derecha y la Concertación)? Suponiendo el carácter bien fundado de este clivaje, ¿en qué reside su eficacia? ¿En la magia polarizadora de sus efectos con ocasión de un evento electoral tan extraordinario como el plebiscito? ¿En los aprendizajes políticos que los dirigentes partidarios y los electores hicieron a lo largo de 17 años de dictadura militar? ¿En las lealtades entre élites que la misma condición opositora pudo engendrar? Más profundamente, ¿qué puede haber de común entre clivajes de origen social cuya esperanza de vida política se mide en décadas, y fisuras eventualmente destinadas a desaparecer una vez que la dicotomía entre democracia y dictadura deja de hacer sentido a medida que la democracia chilena se consolida? Si bien los autores no ignoran que el clivaje entre el Sí y el NO no es el único principio organizador del sistema de partidos, puesto que ellos mismos señalan la existencia de otras nuevas fisuras “como la que contrapone protección del medioambiente / crecimiento económico” (Tironi y Agüero, 1999, p. 162), ¿de qué manera este último clivaje se imbrica con el primero? No cabe duda de que el conflicto democracia / dictadura se erige como "alineamiento dominante” (p. 162), subordinando a los antiguos clivajes que dieron origen al sistema de partidos en 
Chile, pero ¿de qué modo? ¿En qué se traduce este clivaje dominante respecto de las fisuras originarias? ¿En el predominio de los issues derivados del clivaje democracia / dictadura tanto en la oferta electoral como en el discurso de las coaliciones, absorbiendo las cuestiones valóricas y socioeconómicas? ¿En la completa sustitución de las causas por las cuales se lucha o se compite, lo que vendría a significar una total transformación del sistema de partidos? ¿Cómo se adecúan las identidades partidarias y las culturas políticas de los segmentos más politizados del electorado a esta nueva configuración? Ninguna de estas preguntas recibe respuestas satisfactorias por parte de Tironi y Agüero, quienes se contentan con sugerir -a partir de la constatación del surgimiento de nuevas alianzas, de un estrechamiento de la distancia ideológica entre los partidos y la aparición de lealtades transversales al interior de las élites de la Concertación- que los electores orientan cada vez más sus votaciones hacia las dos grandes coaliciones. Pudiendo ser eventualmente cierto que los electores se orientan cada vez más en relación a las coaliciones existentes, los autores hacen caso omiso de una de las tantas lecciones de método de Durkheim, esto es que "ilustrar una idea no es demostrarla".

Torcal y Mainwaring (2003) se proponen precisamente demostrar el persistente impacto de clivajes de naturaleza política con el fin de asentar el juicio de discontinuidad del sistema de partidos chileno. Para tal efecto, los autores inician su demostración reinterpretando la teoría de los clivajes de Lipset y Rokkan. Haciendo gala de un gran conocimiento de la literatura sobre sistemas de partidos, Torcal y Mainwaring observan con razón que la interpretación dominante de los clivajes y de sus efectos se ha basado en juicios más sociológicos que políticos, en el sentido en que los clivajes que se encuentran en el origen de los sistemas de partidos en Europa son el fruto de transformaciones de las propias sociedades del viejo continente. Estos clivajes sociales, una vez "congelados" (para retomar los términos de Lipset y Rokkan), engendran respuestas políticas en la forma de partidos y sistemas de partidos, con lo cual estos últimos tienden a ser concebidos por la interpretación sociológica dominante como aspectos "secundarios" (Torcal y Mainwaring, 2003, p. 56), o si se quiere como epifenómenos.

Al igual que Tironi y Agüero, Torcal y Mainwaring proponen invertir la lógica generativa de los clivajes, hipotetizando que la propia acción política (lo que estos autores llaman la "agencia política” (p. 56)) "puede (re) crear identidades socio-políticas, polarizar o difundir conflictos sociales potenciales", e incluso "alterar la naturaleza de los conflictos sociales a través de políticas adoptadas por el gobierno" (p. 56). Hay allí, qué duda cabe, un verdadero coup de force teórico, el que es sometido a verificación empírica 
sobre la base de cuatro encuestas, tres de las cuales fueron realizadas a mediados de la década del noventa, y la última pocos meses antes del quiebre democrático de 1973 en el Gran Santiago. Independientemente de las diferencias de diseño muestral que se aprecian entre las encuestas del Centro de Estudios Públicos (probabilísticas) y del Latinobarómetro (una hibridación entre diseños probabilísticos y de cuotas) - lo que vuelve particularmente delicada la comparación de los datos obtenidos, una dificultad que es ignorada por los autores-, Torcal y Mainwaring testean distintas variables sociales y políticas a partir de la técnica de los odds ratios, con el fin de verificar o invalidar la hipótesis de primacía de la "agencia política" (aquí constituida como variable) respecto de variables sociales. Transformando en variable dependiente a "la competencia entre pares de los cinco partidos electoralmente más importantes en el Chile contemporáneo” (p. 59), esto es, dicotomizando las preferencias electorales respecto de parejas de partidos tales como PDC v/s PS, los autores detectan un "impacto modesto" de la clase social sobre las preferencias de coalición a partir de 1989 (p. 63). Así, "la votación de clase antes de 1973 no era tan intensa en Chile como algunos autores lo habían indicado" (p. 69), una afirmación interesante que tiende a desmentir un arraigado sentido común en Chile respecto de la relación — tal vez más políticamente constituida que empíricamente verificada- entre clases sociales y partidos. No muy distinta es la eficacia de la religión, una variable que a nivel del Gran Santiago "era un predictor altamente significativo de la preferencia de coalición en los 60" (Torcal y Mainwaring, 2003, p. 65), lo que deja de ser cierto en los años 90. Sólo la residencia, dicotomizada entre el espacio urbano y rural, se presenta como variable moderadamente significativa, sin que ello permita asentar de modo definitivo un juicio de causalidad a favor de variables sociales. Por consiguiente, los autores no dudan en concluir que las identidades políticas y las preferencias partidarias "no son determinadas o predichas por las localizaciones sociológicas de los actores” (p. 84).

Si bien el escaso significado estadístico de estas dos variables sociales vuelve verosímil la hipótesis de predominio de las variables políticas en la configuración de las preferencias electorales sobre las que se sustenta el sistema de partidos, los autores también testean la incidencia de estas variables, así como su valor predictivo. Para tal propósito, Torcal y Mainwaring evalúan seis variables políticas independientes, una de las cuales permite poderosamente discriminar entre los partidarios de las dos principales coaliciones en la década del noventa. Esta variable tan discriminadora se refiere a la pregunta de encuesta, regularmente formulada por el Latinobarómetro, acerca de la preferencia del tipo de régimen político. Es así 
como esta variable es "el mejor predictor de la identificación ideológica de los votantes después de controlar la clase, la edad y el género en el apoyo a un régimen democrático, seguido por percepciones de distribución del ingreso y la religiosidad" (Torcal y Mainwaring, 2003, p. 77). No parece discutible la importancia de esta variable eminentemente política, no sólo por razones de técnica estadística, sino sobre todo por las conclusiones más generales que Torcal y Mainwaring sacan respecto del predominio de las variables políticas en desmedro de otras variables sociales.

A decir verdad, más que de predominio, de lo que cabe hablar es de autonomía de las variables políticas para explicar el modo y el tipo de configuración del sistema de partidos chileno. La distinción no es baladí, ni menos el fruto de una coquetería del lenguaje. En efecto, la demostración de Torcal y Mainwaring no sólo pasa por el uso diestro de la técnica de los odds ratios, sino que se basa en el crucial supuesto de "autonomía del elemento político" de un clivaje, lo que se traduce en "la capacidad de los actores políticos de forjar, a través de su discurso y la fabricación de políticas, identidades políticas y preferencias partidarias” (p. 84). Puesto en estos términos, se trata de un supuesto adaptado a las necesidades de la demostración de los autores, susceptible de avalar teóricamente los resultados arrojados por el uso de técnicas estadísticas. Ello implica, por consiguiente, esgrimir buenas razones teóricas para asentar racionalmente el carácter bien fundado del supuesto. Ahora bien, lo interesante del enfoque de Torcal y Mainwaring es que no eluden el trabajo de especificación de un supuesto cuyas implicancias son considerables para el análisis. He allí en donde reside la importancia de la concepción de la causalidad que esgrimen los autores, mucho mayor que los resultados estadísticos alcanzados, quienes señalan que "las variables sociológicas y demográficas se encuentran en un nivel diferente de causación respecto de las variables políticas” (p. 70). Más precisamente, los autores presumen que las variables sociales se encuentran "más distantes" de la variable dependiente (la competencia entre los cinco principales partidos chilenos a partir de parejas dicotomizadas) que las variables políticas, lo que significa que "las variables políticas actitudinales” están más próximas de la variable dependiente "en la cadena de causación” (p. 70). Convengamos que es esta concepción de la causalidad la que justifica la reinterpretación (política) de la teoría de los clivajes (sociales) de Lipset y Rokkan, y le confiere un mayor alcance a los resultados obtenidos por Torcal y Mainwaring. Pero suponiendo que esta interpretación de los clivajes fuese teóricamente admisible, ¿cuáles son sus implicancias para interpretar resultados empíricos? En primer lugar, afirmar que "la política es responsable de la creación, transformación, profundización o di- 
fusión de conflictos sociales y económicos específicos" (Torcal y Mainwaring, 2003, p. 59), equivale a dar por empíricamente asentado el supuesto de una homogénea exposición de la población a los discursos políticos, las plataformas electorales, los programas partidarios y las tomas de posición de sus dirigentes. Aun más. El supuesto de una mayor causalidad de las variables políticas, fundado en la premisa teórica de una mayor cercanía respecto de las preferencias electorales, elude el análisis de lo que estos electores hacen con lo que el lenguaje estadístico llama "variables sociales", o mejor dicho se economiza el esfuerzo de reflexionar sobre los usos y retraducciones políticas de la clase social, de la religión o del lugar de residencia. Más profundamente, la estrategia de análisis de Torcal y Mainwaring adolece de un vicio de origen, anti-sociológico si se quiere, cuya consecuencia es vaciar el espacio político de todo componente o dimensión social, presumiendo que las preferencias de los electores se engendran causalmente desde racionalidades políticas subsumidas por una variable independiente estadísticamente discriminante (preferir un régimen democrático o un régimen autoritario). En tal sentido, la demostración del predominio de las variables políticas para dar cuenta del surgimiento de clivajes sobre los que se instituye un sistema de partidos, se paga al precio fuerte del irrealismo social, al desconocer que la política, más allá de su especificidad como práctica que se ejerce en un espacio diferenciado, "es un conjunto de actividades especializadas a la vez que una dimensión no siempre explícita de las relaciones sociales” (Lagroye, 1994, p. 10) y, peor aún, al olvidar que la política es también "producción social” (Lagroye, 2003, p. 4).

En cierto sentido, el trabajo de Jones y Mainwaring (2003) proporciona evidencia a favor del enfoque de Torcal y Mainwaring. En efecto, los dos primeros autores, al interesarse en los niveles de nacionalización de los sistemas de partidos y al concluir en un alto nivel de nacionalización del sistema de partidos en Chile $^{20}$, permiten presumir que en los sistemas que exhiben un elevado "score de nacionalización" predominan variables e issues estructurantes en desmedro de variables sociales. La propuesta de Jones y Mainwaring es sumamente interesante para la discusión acerca de la permanencia o la discontinuidad del sistema de partidos en Chile puesto que, sin interesarse en la pregunta de la génesis de los clivajes, el alto nivel

${ }^{20}$ Una tarea que es abordada a partir del análisis de 15 países latinoamericanos, mediante la construcción de coeficientes invertidos de Gini, en donde un alto nivel de nacionalización (como en Chile) significa que los partidos que recogen el apoyo de más del 5\% del electorado obtienen "porciones iguales de votación a través de todas las unidades sub-nacionales” (Jones y Mainwaring, 2003, p. 142). 
de nacionalización que ellos detectan en un nivel agregado de los resultados electorales, al distribuirse relativamente bien a lo largo del territorio, podría constituir evidencia adicional a favor de la eficacia de issues políticamente homogeneizadores de la oferta y de las preferencias electorales. Sin embargo, Jones y Mainwaring descartan de plano esta posibilidad, al señalar que "la nacionalización de los partidos" es "analíticamente distinta” de la pregunta de "si los votantes están respondiendo a temas nacionales" (p. 144). Por consiguiente, la contribución de Jones y Mainwaring aporta información abundante acerca del nivel de nacionalización del sistema de partidos en Chile, pero no respecto de su modo de configuración, ni menos sobre la génesis (política o social) de sus clivajes. Así, toda una discusión se hace posible a partir de este estudio, puesto que el elevado nivel de nacionalización que los autores ponen en evidencia se fundamenta en una verdadera operación quirúrgica sobre los partidos que compiten en elecciones, al hacer como si las coaliciones fuesen organizaciones partidarias, lo que plantea la pregunta de la unidad de análisis de la política y de las elecciones en Chile.

Concluyamos esta sección con una pregunta de fondo. ¿Hasta qué punto, y en qué medida, la noción de "sistema de partidos" es útil para el análisis científico? Más allá de las referencias obligadas a los clásicos estudios de Duverger (1976) y de Sartori (1980), ¿por qué apegarse a la noción de "sistema de partidos", y no solicitar otras categorías, como por ejemplo la de "campo político"21? La pregunta se torna tanto más pertinente cuanto mayores son las dudas referidas a lo que se gana y se pierde en comprensión con la noción de "sistema de partidos". Si de "sistema" cabe hablar, entonces el objeto de investigación que debiese predominar estaría dado por las relaciones e interacciones entre partidos, cuya regularidad es lo que hace posible la existencia de un sistema. El problema es que la literatura especializada se interesa más en tal o cual aspecto de un "sistema" de partidos (orientaciones agregadas del voto no desglosadas por variables, tipos de clivajes que originan partidos políticos individuales o coaliciones de partidos, representaciones [espaciales o formales] del electorado sobre las que se asientan localizaciones [espaciales o formales] de partidos, candidatos o coaliciones que son retraducidas como ofertas, etc.), que en los patrones de interacción entre partidos. Más allá de las frecuentes referencias a las distancias ideológicas relativas que separan a los partidos, y al tipo de competencia (centrípeta o centrífuga) que éstos producen, pocas veces es constituida como objeto de estudio la noción de "sistema". Pudiendo ser cierto que el electorado de tal o cual partido o coalición orienta

${ }^{21}$ Para una sociología del campo político, cf. Bourdieu (1981) y Gaxie (2003). 
su conducta en relación a tal o cual issue o conjunto de issues, o que tal o cual clivaje engendra determinados tipos de partidos o alianzas de partidos, ello no significa que se esté trabajando sobre la noción de "sistema de partidos”. En tal sentido, tal vez resulte más útil y fecundo para el análisis científico interesarse en los espacios de competencia y en sus actores (lo que la sociología de Bourdieu entendió por "campos”, y no por "arenas" como a veces se piensa, entendiendo por estas últimas enclaves específicos de contienda política, sean estos parlamentos o Congresos, gobiernos e incluso partidos), evidenciando lo que se encuentra en juego en ellos, los recursos con los cuales compiten los agentes, las estrategias implementadas por los contendores y el trabajo de construcción de los issues que es emprendido por parte de quienes pugnan por conquistar posiciones de dominación, pero también por aquellos otros agentes que comentan el juego político, poniéndolo en forma y dotándolo de sentido (analistas, periodistas, especialistas de encuestas, cientistas políticos, sociólogos, economistas, historiadores, etc.). Si bien una estrategia de este tipo supone desechar la noción de "sistema", ésta tiene a su favor el abogar y hacer suyas las bondades del pensamiento relacional que se desprende de la sociología weberiana, interpretando tal o cual oferta electoral (o más precisamente, de "bienes políticos") en relación con la de otros competidores, interesándose en el modo de construcción de lo que se encuentra en juego tomando en serio el hecho de que su génesis reside en la competencia entre múltiples agentes, y dando cuenta de lo que cada posición adoptada sobre intereses supuestos de los electores es, también, una toma de posición respecto y en contra de otras posiciones y tomas de posición. Curiosamente, aquello que es omitido por los estudios electorales y sobre el "sistema de partidos" en Chile, esto es, los patrones de relación e interacción entre fuerzas políticas, se transforma en objeto principal de investigación de una sociología política que se toma en serio todo lo que se juega en las confrontaciones, alianzas y colusiones que son tan propias del campo político.

\section{IV. ¿Qué es lo que se debe analizar?: partidos, coaliciones y la pregunta de la unidad de análisis}

Uno de los aspectos más controversiales de la literatura sobre partidos políticos en Chile se refiere a la manera de cómo medir su número. En primera aproximación, el trabajo de contabilización de partidos no debiese ser particularmente problemático a partir de 1989 puesto que, incluso admitiendo la pertinencia analítica de la observación de Montes, Mainwaring y 
Ortega (2000) acerca de una fuerte rotación de las etiquetas partidarias desde 1932 en adelante, el volumen de organizaciones políticas se reduce drásticamente una vez que se inicia la transición a la democracia: en tal sentido, el solo hecho de que la Concertación pase de 17 partidos nominales a cuatro fuerzas reales a los pocos años es prueba fehaciente de ello. Como es bien sabido, es el propio Sartori quien ya había señalado la dificultad de contabilizar a los partidos con el fin de caracterizar a los sistemas que éstos conforman, al postular la necesidad de transformar en objeto de adición a "los partidos que importan", para lo cual proponía "normas para contar" (Sartori, 1980). Sin embargo, es en Laakso y Taagepera (1979) en quienes recae el mérito de haber explicitado metodológicamente estas normas, mediante una fórmula tan célebre como influyente destinada a determinar el "número efectivo de partidos", distinguiendo entre partidos electorales (cuyo número resulta de una serie de operaciones realizadas sobre los votos populares obtenidos) y partidos parlamentarios (cuyo volumen se determina en función de los escaños alcanzados). No puede entonces sorprender que en el origen de la controversia en Chile se encuentren dos usos irreconciliables del índice de Laakso y Taagepera, explicable por la elección de dos unidades distintas de análisis: por una parte coaliciones, y por la otra partidos políticos individuales.

La elección de cualquiera de estas dos unidades de análisis dista mucho de ser inocua, puesto que ésta arrojará números efectivos de partidos sumamente distintos y, más importante aun, permitirá emitir juicios diferentes acerca de los niveles de fraccionamiento de los sistemas de partidos. $\mathrm{Al}$ respecto, Altman (2004) plantea acertadamente los términos de la dificultad respecto de las elecciones chilenas, al señalar que "el actual sistema electoral imperante en Chile limita al investigador por la sencilla razón de que los resultados electorales medidos al nivel de partidos pueden estar confundiéndonos en cuanto a las lealtades partidarias de los electores" (p. 59, el subrayado es nuestro). En efecto, al optar por los partidos políticos individuales que compiten por votos populares y escaños, es posible que tras la decisión de voto por tal o cual candidato que es portador de una sigla partidaria, predomine una adhesión del elector por una coalición, una hipótesis que puede eventualmente ser opacada por la afiliación partidaria del candidato. Pero la dificultad que se le plantea al investigador también se refiere a la incidencia del sistema binominal. La idéntica magnitud distrital $(M=2)$ que se observa para todas las elecciones de diputados y senadores en Chile obliga, en el caso de la Concertación, a complejas negociaciones entre sus cuatro partidos, de lo cual resulta una oferta de candidatos que no les permite a todos los socios de la coalición competir en todo el 
territorio. Se entiende, entonces, que la determinación del número efectivo de partidos sea particularmente compleja para el investigador, en la medida en que este número no se obtiene como consecuencia de una oferta de candidatos afiliados a partidos distribuidos de modo regular a lo largo y ancho de los distritos diputacionales y de las circunscripciones senatoriales. Esto es lo que explica que numerosos investigadores opten por constituir como unidad de análisis y de adición a las coaliciones más que a los partidos, argumentando que cualquier otra decisión no permite emprender un trabajo de conteo que tome en consideración la totalidad del territorio electoral.

Es así como Cabezas y Navia (2005), intentando medir el número de partidos y de candidatos, optan por realizar esta operación "a nivel de distrito" y no a nivel nacional, fundamentando esta decisión en los riesgos de medir el número "absoluto" de candidatos y partidos, en el marco de un sistema electoral que no admite la distribución equitativa de los partidos políticos individuales a lo largo del territorio en elecciones legislativas. En apoyo de esta elección metodológica, los autores establecen la diferencia entre dos distritos hipotéticos con 6 candidatos cada uno, en donde en uno dos candidatos "concentran el $80 \%$ de la votación", mientras que en el otro cada uno de los seis candidatos "obtiene una votación cercana al 15\%" (p. 39). Cabezas y Navia sostienen que el tipo de competencia que estos dos distritos hipotéticos engendran es muy distinto, razón por la cual consideran que el distrito en donde dos candidatos monopolizan el $80 \%$ de los sufragios "debiera ser considerado como con un menor número de candidatos” (p. 39), lo cual, siendo matemáticamente evidente, no explica ni justifica el umbral del $80 \%$. En tal sentido, cabría mejor fundamentar el umbral pasado el cual se puede apreciar una disminución significativa del número de candidatos. No obstante, Cabezas y Navia infieren de estas dos hipótesis de competencia distrital la necesidad de transformar a cada uno de los distritos diputacionales en el territorio desde el cual se establecen los valores promedios de las candidaturas, lo que equivale "a una forma efectiva de medir las diferencias entre partidos y coaliciones" en completa independencia de su militancia partidaria (p. 40). La consecuencia de esta decisión de método es que lo que el investigador contabiliza son candidaturas individuales avaladas por coaliciones y no por partidos, lo que permite obtener bajos números promedios de candidaturas a lo largo de cuatro elecciones a la cámara baja. Aun más. Al concebir a las dos principales coaliciones como partidos, los autores infieren de la interacción entre una de las propiedades formales del sistema electoral (la magnitud distrital), la composición de las dos coaliciones principales (en el caso de la Concertación, cuatro partidos) 
y la oferta de candidatos por coalición de acuerdo con las expectativas de éxito en la conquista de escaños, una "tendencia creciente" a que "cada partido" (entendiendo como tal una coalición) "tenga como máximo un candidato por distrito", un escenario que, de producirse, lograría que "los valores del NEC [Número Efectivo de Candidatos] y NEP [Número Efectivo de Partidos]" sean "idénticos" (p. 44). Si bien no parece discutible esta "tendencia creciente”, lo que sí resulta controversial es la constitución de las coaliciones como unidad privilegiada de análisis, puesto que se presume que éstas actúan como si fuesen un solo partido. Hay allí una decisión metodológica cuyas implicancias trascienden con creces la lógica del método.

En primer lugar, resulta ser muy irrealista concebir a las coaliciones como si fuesen partidos, aun cuando la determinación de su número efectivo pueda producir una apariencia de verosimilitud. En efecto, nada permite sostener que la orientación del voto de los electores esté entera o mayoritariamente anclada en una oferta coalicional de candidatos, en el entendido de que en la gran mayoría de los distritos y circunscripciones lo que se observa es una fuerte competencia entre partidos de una misma coalición por la obtención del único escaño por el cual es razonable competir. Pero en segundo lugar, no es posible desconocer la importancia de los partidos políticos individuales tanto en la conformación de las listas como en las interpretaciones posteriores de los resultados, en la medida en que en el origen de estos dos momentos de la elección se encuentran siempre presentes los intereses particulares de los partidos, de los cuales no se puede presumir que se subordinan a los intereses colectivos de la coalición. Por consiguiente, la decisión metodológica de constituir en unidad de análisis a la coalición, presuponiendo que ésta es un partido, produce al final de cuentas una simplificación excesiva de la explicación, al reducir artificialmente el número de candidatos y de partidos, y al inferir patrones de competencia que se ajustan a la minimización del volumen de actores que es ejercida por el investigador. Es así como Cabezas y Navia obtienen un número efectivo de candidatos de 3,94 para el periodo 1989-2001, un valor promedio que oscila entre un máximo de 4,20 (en 1989) y un mínimo de 3,73 (en 2001). En cuanto al número efectivo de partidos, el promedio para este mismo periodo es de 3,84, con variaciones que van desde un 3,95 (en 1989) hasta un 3,71 (en 2001) (p. 41). En ambos casos, el número efectivo se obtiene a nivel distrital y sobre la base de los votos populares. Distinto es el caso cuando el número efectivo de partidos se obtiene en función de los escaños. Independientemente de que el análisis se realice a nivel distrital o nacional, el número efectivo de partidos se reduce dramáticamente. Es así como los 
autores de La Política Importa (Payne, Zovatto, Carrillo y Allamand, 2003, p. 129) contabilizan 2,04 (en 1989), 2,00 (en 1993) y 2,07 (en 1997) partidos efectivos, cifras que se fundamentan en la decisión metodológica de constituir a la coalición en unidad de análisis, siendo ésta asimilada a un partido. Así, no obstante la legitimidad de las razones metodológicas que justifican esta decisión, las consecuencias que se derivan de ella son considerables. En efecto, si ya resultaba problemático contentarse con un modesto 3,84 partidos efectivos (como se desprende del trabajo de Cabezas y Navia), esto resulta aun más cierto con la contribución de Payne, Zovatto, Carrillo y Allamand (2003), quienes eliminan definitivamente a los partidos políticos individuales, proporcionando una (falsa) representación bi-partidaria, presuntamente ajustada a los efectos (mecánicos) del sistema binominal y, peor aun, a los supuestos y voliciones esgrimidos por sus promotores. En tal sentido, el artificio de concebir coaliciones como si fuesen partidos, pudiendo eventualmente justificarse en razones metodológicas, es productor de una representación reduccionista del sistema de partidos chileno, haciendo coincidir las voluntades ideales de la ingeniería electoral con una expresión empírica que apenas disimula su función de ratificación del triunfo de la razón ingenieril. Sin duda, Altman (2005) no se equivoca al señalar que "la simultaneidad de las elecciones ejecutivas y legislativas tiene un efecto reductor del número de partidos” (pp. 3-4), como bien lo muestra por lo demás la propia contribución de Cabezas y Navia (2005), al señalar que "mientras más candidatos se presenten a la reelección, menor es el valor del NEP y NEC", aun cuando los autores tienen la precaución de identificar la dirección de una tendencia sin que el número de casos sobre el que ellos trabajan arroje resultados estadísticamente significativos (p. 45). Pese a todo, las implicancias de la unidad de análisis escogida siguen siendo las mismas, tanto desde el punto de vista de la representación simplificada del juego electoral que éstas hacen posible como en lo que se refiere a los juicios generales sobre el sistema de partidos. Al respecto, si Jones y Mainwaring (2003) pueden afirmar que "la Concertación y la Alianza poseen altos niveles de nacionalización” (p. 157), ello se debe a que los resultados electorales son endosados a las coaliciones más que a los partidos, una operación que les permite representar a las fuerzas políticas en la forma de partidos cuyo arraigo electoral se distribuye de modo regular a lo largo de los distritos diputacionales... al precio fuerte de volver equivalentes lo que es propio de una coalición y lo que es inherente a partidos políticos individuales.

Lo anterior explica que muchos autores se hayan propuesto rebatir la pertinencia de una decisión presuntamente metodológica, al ser productora 
de representaciones del juego electoral que violentan la realidad de sus actores. En tal sentido, la severa crítica de Siavelis (1997) se sustenta en una posición de principio, según la cual "los partidos más que las listas son las unidades fundamentales de análisis para comprender la composición del sistema de partidos chileno" (p. 654). Sin desconocer la existencia de fuertes “incentivos para formar pactos electorales bajo el sistema binominal” (independientemente de la pregunta acerca de la naturaleza — supuesta, mecánica o empírica - de estos incentivos), Siavelis afirma que "es un error simplemente tratar a las actuales coaliciones existentes como si fuesen partidos” (p. 655). ¿Cómo demostrar esta afirmación? Solicitando, a diferencia de tantos otros autores, mediciones del tamaño de los partidos a partir de las que es posible determinar su número, con lo cual Siavelis logra justificar la unidad partidaria de análisis. De este modo, Siavelis pone en evidencia la figura estadística de los “partidos de simple relevancia”, entendiendo como tales a aquellas organizaciones que "poseen al menos un representante en la Cámara de Diputados y que fueron nacionalmente votados al menos con un 5\%” (p. 660). Al proceder de esta manera, el autor determina una gran continuidad entre el periodo pre-autoritario y los primeros años de la transición a la democracia en Chile, mostrando que "el número de partidos que lograban más del 5\% de los votos y que obtenían representación” en la Cámara de Diputados en las elecciones de 1989 y 1993 es “más o menos el mismo” que antes del golpe de Estado de 1973 (p. 660). Incluso empleando el índice de Laakso y Taagepera, Siavelis destaca un número de partidos cercano "al promedio histórico" (p. 661) 22 , un resultado que contradice tanto las cifras de Cabezas y Navia (2005) como los promedios de Payne, Zovatto, Carrillo y Allamand (2003), lo que se explica por la decisión de constituir en unidad de análisis a los partidos individuales y no a las coaliciones. Ciertamente, las diferencias numéricas que se desprenden de estos tres trabajos no sólo no son menores, sino que admiten interpretaciones distintas del sistema de partidos en Chile en la década del noventa. En primer lugar, Siavelis rebate el efecto reductor del número de partidos que comúnmente se le atribuye al sistema binominal. Pero sobre todo, la representación del sistema de partidos que se desprende de la demostración de Siavelis contradice fuertemente la imagen que proporcionan por una parte la contribución de Cabezas y Navia (2005) y, por la otra, el estudio de los autores de $L a$ Política Importa (2003). Mientras que para Siavelis el tipo de fragmentación del sistema de partidos chileno es fundamentalmente el mismo entre perio-

${ }^{22}$ Es así como entre 1925 y 1973, "el número efectivo de partidos electorales ascendió a casi siete”, mientras que entre 1989 y 2001, este mismo número "ha oscilado entre 7,8 y 6,8” (Siavelis, 2005b, p. 13). 
dos muy distantes en el tiempo desde un punto de vista numérico, esto deja de ser cierto para los otros autores, quienes destacan su desfragmentación. Si bien Siavelis reconoce la emergencia de nuevos patrones de alianzas tendientes a configurar un juego de tipo bi-coalicional, eso no le impide observar que el sistema binominal "ha contribuido a la existencia de pequeños partidos” (Siavelis, 1997, p. 663), no sólo porque éstos logran alcanzar votaciones levemente superiores al 5\% y conquistar algunos escaños, sino porque su existencia ha sido el fruto de la adaptación a la lógica del sistema electoral "mediante la negociación" con partidos de mayor envergadura (p. 663). Esta última apreciación es relevante, puesto que incorpora una dimensión más cualitativa y realista de las relaciones entre partidos de desigual tamaño que forman parte de una misma coalición, la que es completamente obviada, a continuación de su "metodológica" eliminación, por los autores que consideran a las coaliciones como partidos.

El enfoque de Siavelis (1997), así como el número de partidos al que llega y el juicio de continuidad del sistema de partidos que este autor emite, es consistente con sus contribuciones posteriores, especialmente con aquellas en las que analiza el modo de construcción de las listas de candidatos afiliados a partidos de distinto tamaño. En tal sentido, las negociaciones que se encuentran en el origen de las listas binominales de candidatos se realizan entre partidos individuales más que al interior de una coalición cuyo valor y relevancia serían mayores, tomando en consideración sus respectivos tamaños relativos con el fin de identificar los "partidos ancla" tanto a nivel de lista como de sub-pacto con el fin de comprender la "lógica oculta” de la selección de candidatos (Siavelis, 2002b).

A decir verdad, la posibilidad de esta controversia entre distintos números efectivos de partidos ya había sido intuida por Laakso y Taagepera (1979), cuando estos autores señalaban que las tabulaciones de los datos electorales podían dar pie a agrupamientos de pequeños partidos en una categoría única (como por ejemplo la categoría "Otra” o "Diversa”), siendo eventualmente legítimo tratarlos "como si fuesen un simple partido” (p. 13). Así, los autores que tratan a las coaliciones como si fuesen partidos podrían encontrar un aval en Laakso y Taagepera. Sin embargo, a menudo se olvida que Laakso y Taagepera tuvieron la precaución de señalar los riesgos involucrados por una decisión de método como la que aquí nos ocupa, como por ejemplo desembocar en "una sub-estimación de la fragmentación" (p. 13), o al revés cuando el investigador se propone incluir en su análisis a un número muy amplio de partidos, lo que podría llevar a "una sobre-estimación de la fragmentación” (p. 13). Lo que realmente importa destacar de la elogiable vigilancia metodológica de Laakso y Taagepera es la idea de que 
cualquier tipo de decisión o estrategia de análisis conlleva riesgos que cabe explicitar, de los que son una clara ilustración tanto los usos de las categorías "Otra” o "Diversa” como la conversión de la coalición en partido.

No parece posible dirimir definitivamente esta controversia, salvo si se acepta que los costos para el conocimiento no se distribuyen de igual modo entre la decisión de constituir a la coalición como unidad de análisis bajo el supuesto de que ésta actúa y es medida como si fuera un partido, y la elección metodológica de privilegiar al partido como objeto de estudio en desmedro de las coaliciones. Si bien el juicio acerca del multipartidismo en Chile se aviene mejor con las investigaciones que privilegian al partido como unidad de análisis, éste se sitúa en un plano netamente a-temporal, al dar lugar a evaluaciones del tipo de relaciones que se desprenden de tal o cual número efectivo de partidos. Pero esta misma decisión de método no permite dar cuenta de las lógicas de variación del número de partidos a lo largo del tiempo. En tal sentido, es importante sacar todas las consecuencias de la propuesta de Colomer (2004c), según la cual el número de partidos requiere de parte del investigador entender que éste es el fruto de historias largas, lo que significa que más allá de los efectos (supuestos) producidos por la introducción de un sistema electoral, "los sistemas multipartidistas son un hecho anterior y no sólo subsiguiente a la adopción de reglas de asamblea con representación proporcional o reglas presidenciales con segunda vuelta” (p. 114). Puede entonces entenderse que el afán de determinar el número efectivo de partidos y de identificar variaciones entre dos o más elecciones, sea portador de un sesgo histórico, al desconocer que la existencia de los partidos, y por tanto de su número, se explica en gran medida por la historia, la que no es reducible a la mera cronología entre eventos eleccionarios.

\section{Explicando el voto de los chilenos: entre el lenguaje de las variables y la racionalidad de los agentes}

Si bien la explicación del comportamiento electoral en Chile se encuentra lateralmente abordada por los estudios que hemos discutido hasta ahora, desde la función ordenadora de la oferta de los candidatos y de las preferencias de los electores ejercida por el votante medio, hasta la incidencia de los clivajes sobre la orientación de los votantes, resulta pertinente detenerse en aquellas investigaciones que se interesan explícita y principalmente en la conducta electoral de los chilenos.

Es sin duda en Navia en quien recae el mérito de haber proporcionado la más completa representación bruta del comportamiento electoral de 
los chilenos, por una parte en lo que concierne las tasas de participación, abstencionismo y de votación nula y blanca (Navia, 2004; asimismo, Navia y Joignant, 2000), y por la otra en lo que atañe a sus variaciones en función de aspectos institucionales tales como el tamaño de los distritos (Cantillano y Navia, 2005). Es así como el electorado chileno ha experimentado un notorio congelamiento de su volumen entre 1988 y el 2001, pasando de una excepcional tasa de inscripción en los registros electorales con ocasión del plebiscito de 1988 (superior al 90\% de la población en edad de votar) a un 76,9\% en el contexto de las elecciones legislativas del 2001. Pero más allá del congelamiento del volumen del electorado inscrito en los registros electorales, Navia destaca su envejecimiento, puesto que según sus estimaciones las personas nacidas "después de 1970 representan hoy entre un 74,2\% y 80,4\% de los no inscritos” (Navia, 2004, p. 96). Más precisamente, la envergadura del envejecimiento del padrón electoral se traduce en el hecho de que "si en 1988 un tercio de los inscritos era menor de 30 años, el 2001 sólo lo era el 13\%” (p. 88). Desde el punto de vista de la representación efectiva en la Cámara de Diputados entre 1989 y el $2005^{23}$, se aprecia un sostenido declive a lo largo de 16 años, puesto que si en 1989 esta tasa ascendía a un 74,5\%, el 2005 desciende a un 53,3\%. La explicación de este declive reside en el regular aumento del número de personas en edad de votar que no se inscribe en los registros electorales, lo cual, sumado a los electores que estando inscritos votan por fuerzas que no obtienen escaños, votan en blanco o anulan su sufragio, hace que el $46,7 \%$ de los adultos carezca de representación en la cámara baja. Junto a esto, se aprecia un “constante aumento del abstencionismo", el que pasa de "389.891 en el año 1989 (5,3\% de los inscritos) a poco más de 1,1 millón en el año 2005 (13,4\% de los inscritos)" (FLACSO, 2006, p. 28). Naturalmente, no es posible explicar el aumento de este tipo de comportamiento, como tampoco los regulares niveles de votación nula y blanca que se observan en Chile, puesto que, como bien lo señala Navia (2004), resulta "incorrecto" catalogar a los votos nulos y blancos como un "voto de protesta” (p. 93).

Una de las variables que participa de la explicación de la declinación del número de votantes reside, presumiblemente, en "fenómenos particulares a determinados distritos" (Cantillano y Navia, 2005, p. 16) que cabría analizar más detenidamente, en la medida en que los autores detectan una "divergencia en la razón entre inscritos y población” que hace que ésta no varíe "igualmente en todos los distritos" (p. 15). Lo que se desliza en esta

${ }^{23}$ Entendiendo por "representación efectiva” el "porcentaje de votantes en edad de votar que efectivamente expresó su preferencia por una tendencia que finalmente obtuvo una representación en la Cámara”: FLACSO, 2006, p .8. 
observación es la posibilidad de que variables institucionales (tal vez asociadas a los tamaños sumamente irregulares de los distritos) estén incidiendo en las tasas variables de inscripción en los registros electorales: en efecto, "en un buen número de distritos hubo menos inscritos el 2002 que en 1988” (Cantillano y Navia, 2005, p. 15). Idealmente, esta pista debería fomentar estrategias de análisis orientadas a poner en evidencia aspectos locales (como por ejemplo estrategias políticas de inscripciones más o menos masivas en determinados distritos, cuya consecuencia podría ser la disminución del electorado inscrito en otros distritos; tipos de ofertas distritales de candidatos; incidencia de candidatos incumbentes susceptibles de producir elecciones semi o no competitivas en ciertos distritos, etc.), pero en su ausencia, lo que predomina son análisis de nivel agregado que testean la incidencia de variables institucionales en relación con otras variables. Es a esa tarea que se abocan Fornos, Power y Garand (2004), en un trabajo que pretende dilucidar los niveles de participación electoral en 18 países latinoamericanos entre 1980 y el 2000 (uno de los cuales es Chile). Si bien el enfoque comparado de estos autores se sitúa en las antípodas de estrategias de análisis cuyo objeto de estudio está formado por comparaciones entre diferentes aspectos de distritos de un mismo país a lo largo de varias elecciones, éste ofrece sin embargo algunas enseñanzas, especialmente porque "las unidades de análisis son elecciones individuales más que promedios de países", lo que significa que "cada una de las variables independientes es medida en un momento dado del tiempo" (p. 916). Entendiendo que la variable dependiente es, por una parte, la participación electoral en elecciones legislativas (en aquellos países, como Chile, dotados de sistemas bicamerales, la participación se calcula a nivel de cámara baja) y, por la otra, la participación en elecciones presidenciales, Fornos, Power y Garand testean un modelo institucional de explicación y un modelo socioeconómico, cada uno de los cuales se compone de un cierto número de variables. De modo sugerente, los autores encuentran evidencia estadística a favor del modelo institucional, el que se comporta "moderadamente bien", contrastando con el muy débil rendimiento del modelo socioeconómico (p. 924). Es así como estos autores concluyen, no sin antes expresar su sorpresa, que "las elecciones latinoamericanas provocan mayor participación a medida que se mueven hacia distritos uninominales y lejos de una representación proporcional nacional” (p. 925), lo que permite hacer de Chile un país en donde la baja magnitud distrital de las elecciones legislativas explica de modo más consistente la participación electoral, en desmedro de las variables socioeconómicas. Este resultado podría, sin embargo, ocultar la incidencia de otras variables institucionales (como por ejemplo la forma 
presidencial del régimen político en América Latina), puesto que Milner detecta, a partir de datos suizos de un régimen parlamentario, que un sistema proporcional "parece atraer cerca de $5 \%$ más de ciudadanos a las urnas" (Milner, 2004, p. 129), lo que debiese suscitar interpretaciones más prudentes respecto de la incidencia de una variable institucional como la magnitud distrital.

Convengamos que el trabajo de Fornos, Power y Garand (2004) proporciona evidencia agregada y comparada acerca de la incidencia de variables institucionales sobre el nivel de participación electoral. Pero no se puede concluir que se trate de evidencia definitiva y concluyente, en la medida en que el lenguaje de las variables que estos autores asumen permite comprender la participación electoral chilena en relación con otros países del continente, pero no en función de variables que admitan comparaciones entre distritos locales. Aun más. La incidencia de este "modelo institucional" nada nos dice acerca de los efectos de estas variables sobre los distritos, ni menos acerca de los usos que los electores hacen de estas variables.

Esta misma dificultad se observa en la literatura que intenta explicar ya no el nivel de participación electoral en Chile, sino la orientación del voto de quienes están inscritos en los registros electorales en función de variables socio-económicas. Es así como Torcal y Mainwaring (2003) detectan a partir de la técnica de los odds ratios "un efecto discernible, pero modesto" de la variable clase social sobre la preferencia de coalición en la década del noventa, concluyendo que el clivaje de clase no sólo cambió en Chile, sino que "probablemente se debilitó" entre 1973 y 1995 (p. 74). Dow (1998) llega a la misma conclusión a partir de encuestas administradas por él mismo en cuatro de las elecciones senatoriales que tuvieron lugar en 1989, estimando que "ni la clase social ni el género" se encuentran asociados a la elección de tal o cual partido por parte del votante (p. 465). En el caso de Torcal y Mainwaring, la interpretación del efecto modesto de la variable clase se inscribe - como vimos en la sección precedente- en una concepción particular de la causación, a continuación del empleo de datos de encuestas que no siempre son comparables, según la cual la eficacia de las variables sobre el comportamiento electoral se funda en una lógica (presunta) de proximidad relativa de las variables sociales y políticas respecto de las elecciones partidarias que los votantes hacen, mientras que Dow (1998) llega a una conclusión similar usando datos perceptivos generados por encuestas deliberadamente diseñadas para dar cuenta de los principios de orientación del voto en cuatro elecciones senatoriales que tuvieron lugar en un mismo año. No obstante las diferencias metodológicas considerables que separan a estos autores, lo que importa relevar es la similitud de los resultados a los cuales 
llegan. A partir de un estudio más específico, basado en datos electorales, Navia confirma la inexistencia "de una relación relevante entre los niveles socioeconómicos de las comunas" y el voto por el candidato de centroizquierda R. Lagos y por el aspirante de derecha J. Lavín en las elecciones presidenciales de 1999 (Navia, 2003, p. 276). Sin embargo, una vez más nos enfrentamos a la pregunta de cómo esta relación —no significativa a nivel agregado - entre variables socioeconómicas y preferencias partidarias, de coalición o de candidatos se expresa en niveles más desagregados, por ejemplo a nivel de comunas y, sobre todo, en un plano individual. En tal sentido, esta brecha de niveles de análisis puede sesgar la mirada del investigador acerca de la presencia de factores de origen socioeconómico, los que podrían perfectamente aflorar a nivel individual (por ejemplo a través de entrevistas en profundidad o de focus groups: al respecto, cf. Joignant, no publicado), y al mismo tiempo ser ocultadas por preguntas de encuesta que son administradas a centenares de personas o por votaciones generadas por decenas de miles de electores. Sin duda, se trata de una brecha que no es soluble en el estado actual del conocimiento, pero de la cual debiese desprenderse una actitud de vigilancia interpretativa de los resultados sobre los que trabaja el investigador.

Sin embargo, existe una variable en torno a la cual la literatura concuerda acerca de su incidencia sobre la participación electoral y la orientación del voto: el género. Es probablemente Lewis (2004) quien ha proporcionado la descripción más exhaustiva de los efectos de la variable género en el plano electoral. Si bien resulta algo grandilocuente afirmar que su estudio es, "al menos para un país, el examen más completo hasta la fecha de las diferencias de género en las urnas” (p. 720), no se puede desconocer sin embargo que su contribución aborda varios aspectos de la relación entre género y política, desde las diferencias de género en lo que a tasas de inscripción en los registros electorales se refiere hasta las brechas observables entre hombres y mujeres en la dirección del voto, pasando por la identificación de variaciones en materia de abstencionismo y de votaciones nulas y blancas. Después de mostrar la velocidad histórica de la inscripción femenina en los registros electorales una vez que las mujeres acceden a la condición de ciudadanas electoras ${ }^{24}$, hasta que éstas llegan a constituir en 1988 la mayoría del electorado (51,6\%), Lewis describe correctamente las

${ }^{24}$ Para una síntesis histórica del acceso a la ciudadanía electoral de las mujeres a contar de 1934, cf. Valenzuela (1998). Para una historia más amplia de la universalización del sufragio en Chile a partir de la ley del 12 de noviembre de 1874, en cuyo perímetro se observan expresiones incipientes de politización de las mujeres en el último cuarto del siglo XIX, cf. Joignant (2001) y Joignant (2002). 
características de su comportamiento electoral. Si bien el enfoque de Lewis es, en regla general, de naturaleza descriptiva al no basarse en variables diseñadas para producir explicaciones, los datos que este autor proporciona son elocuentes. En primer lugar, el autor señala sin lugar a equívocos que las mujeres, una vez inscritas, "son menos proclives que los hombres a abstenerse de votar”25 (p. 735), incluso cuando éstas no se inscribían en las proporciones de hoy. En segundo lugar, a diferencia de los hombres, las mujeres tienden menos a anular el voto o a votar en blanco (p. 735).

Sin embargo, lo más interesante del trabajo de Lewis es su descripción de la orientación conservadora del voto femenino. Si bien se trata de un aspecto que ya había sido puesto en evidencia no sólo por los historiadores, los sociólogos y los cientistas políticos, sino también por los comentaristas de las elecciones en Chile desde hace mucho tiempo, especialmente por periodistas y analistas con ocasión de la elección presidencial de $1970^{26}$, las diferencias de género siguieron expresándose en las elecciones chilenas desde 1989, aunque con menos espectacularidad. Recordemos que en el plebiscito de 1988, la opción NO triunfó tanto en hombres como en mujeres. Pero al mismo tiempo, si el 58,4\% de la votación masculina optó por el NO, sólo el 51,1\% de las mujeres expresaron esta misma preferencia. No puede entonces sorprender que en las elecciones presidenciales de 1989 y de 1993, ambas ganadas por el candidato de la Concertación, el mismo patrón de votación sea observable: en ambas elecciones, así como en la de 1999 en donde el candidato de derecha se impuso ante el aspirante de la Concertación R. Lagos entre las mujeres, "el candidato de centro-izquierda obtuvo menos apoyo de las mujeres que de los hombres” (Lewis, 2004, p. 727). De modo sugerente, Lewis observa, después de contabilizar el número de candidaturas femeninas a la Cámara de Diputados entre 1989 y el 2001, que, “en promedio”, las mujeres “apoyaron a mujeres más que lo que lo hicieron los hombres” (p. 741). Más profundamente, de acuerdo con los datos electorales empleados por Lewis, este autor desecha la hipótesis de

${ }^{25}$ A modo de ejemplo, la tasa de participación femenina en el plebiscito de 1988 fue de 97,3\%, frente al 96,5\% de los hombres (Lewis, 2004, p. 726).

${ }^{26}$ Una elección que fue ganada por el candidato socialista Salvador Allende, quien obtuvo la primera mayoría relativa con poco más del 36\% de los sufragios frente a sus contendores de entonces, el candidato de derecha Jorge Alessandri y el aspirante del PDC Radomiro Tomic. Ahora bien, en esta misma elección Allende fue ampliamente derrotado por Alessandri entre las mujeres (al obtener este último alrededor de 7 puntos más de apoyo femenino que masculino), del mismo modo que por Tomic, quien también alcanzó una mayor adhesión entre las mujeres respecto de los hombres. Evidentemente, si Allende pudo ganar esta elección, ello se debe a que se impuso abrumadoramente entre los hombres (quienes además formaban la gran mayoría del electorado), con lo cual evidenciaba una verdadera brecha de género en la orientación del voto. 
una solidaridad de género al afirmar que "las mujeres no votarán por otra mujer simplemente sobre la base del sexo" (p. 742), puesto que detrás del sexo femenino de estas candidaturas subyacen afiliaciones partidarias que tienden a reorientar la dirección del voto de las electoras. En efecto, del total de candidaturas femeninas (que el autor denomina "oportunidades") en las que las aspirantes obtuvieron una mayor cantidad de votos de mujeres que de hombres, "38 de las 85 eran para candidatas mujeres de centro-derecha" (p. 741). Este último dato es relevante, puesto que instala la hipótesis de una orientación conservadora de las mujeres que se incrementa con el género. Naturalmente, no es posible testear esta hipótesis a partir de datos electorales, en la medida en que éstos, al no estar sistemáticamente correlacionados con la variable de género, reproducen las condiciones descriptivas de los resultados electorales con los cuales trabaja Lewis.

El trabajo de Altman (2004) aporta evidencia complementaria respecto de la orientación del voto femenino. Es así como, a partir de más de 6.500 observaciones realizadas a nivel de comunas con el fin de determinar el número de votos femeninos que recibe cada candidato en cada localidad restando ese volumen al porcentaje de mujeres que se encuentran allí inscritas, Altman concluye que "la mujer en Chile tiene estadísticamente hablando una inclinación más de derecha que el hombre” (p. 62). Aun más. Procediendo a partir de regresiones multi-variadas, e incluyendo una variable dummy que dicotomiza el sexo del candidato, Altman pone en evidencia "una suerte de solidaridad de género" (p. 62), con lo cual contradice la conclusión a la que llega Lewis. La ventaja del enfoque de Altman reside en su dimensión explicativa, al optar por regresiones multi-variadas sin contentarse con la descripción que suelen admitir los datos electorales cuando éstos no son estadísticamente correlacionados con variables explícitamente constituidas como tales. Sin embargo, el problema planteado por Lewis según el cual detrás de la simetría sexual entre candidatas y electoras se encuentran involucradas etiquetas partidarias que no se distribuyen al azar de las preferencias femeninas, no es completamente resuelto por Altman, quien señala que "si bien la mujer tiene una leve inclinación para emitir un voto de derecha, simultáneamente este voto tiende a favorecer a sus pares de género" (p. 76). Todo indica que, así planteado, el problema no admite una fácil solución, ni menos de carácter decisivo, puesto que lo que se encuentra en juego son concepciones estadísticas de la causalidad. Dicho de otro modo, al constatar que las mujeres votan en proporciones mayores (Lewis) o con mayor regularidad estadística (Altman) por candidaturas conservadoras, no es posible afirmar que el género desempeñe un papel principal o secundario cuando estos mismos candidatos conservadores están 
afiliados a partidos de derecha. En tales condiciones, ¿qué lugar concederle a la variable género? La afirmación de Altman según la cual existiría una suerte de retroalimentación entre la adscripción conservadora de las candidaturas y el voto femenino que opta con mayor frecuencia por estas candidaturas permite presumir, en el mejor de los casos, que el sexo femenino de las candidaturas conservadoras produce un efecto algo parecido al de la consolidación de las preferencias electorales femeninas. De ser así, esto quiere decir entonces que existiría una suerte de pre-determinación de la orientación del voto femenino por el tipo de afiliación partidaria de las candidaturas, lo que se transformaría en determinación cuando estos mismos candidatos conservadores son mujeres. Pero en el peor de los casos, la conclusión de Altman podría ser portadora de una concepción circular de la causalidad, en donde la causa (pongamos por caso la afiliación partidaria de los candidatos conservadores) se transforma en efecto cuando el sexo femenino de estas mismas candidaturas se erige como variable explicativa de la orientación femenina del voto (en cuyo caso, la dimensión de género de los aspirantes deviene en causa principal o relativa, dependiendo de la importancia que el investigador asigna a la etiqueta partidaria que es reivindicada por las candidaturas — femeninas y masculinas_ c conservadoras).

Pero, ¿hasta qué punto la afiliación partidaria de los candidatos constituye un supuesto realista de información para los electores y las electoras, susceptible de transformarse en principio de decisión de voto, cuando al mismo tiempo sabemos que las etiquetas partidarias son fuertemente invisibilizadas durante las campañas electorales? Más precisamente, ¿̇sabemos realmente algo acerca de los usos que los electores hacen de la etiqueta partidaria en coyunturas eleccionarias? Definitivamente no, lo que hace del uso de la etiqueta partidaria por parte del electorado un supuesto que no se verifica necesariamente en la realidad. Es más: aun cuando este supuesto se verificase en el comportamiento electoral, es realista pensar que no todos los electores hacen el mismo uso, algunos eventualmente concediéndole importancia, otros desechándolo como información pertinente, y otros tantos simplemente desconociendo (algo que es muy distinto de la ignorancia racional) el o los partidos que se encuentran detrás de tal o cual candidatura, especialmente parlamentaria y municipal.

Estas preguntas no necesariamente pueden recibir respuestas desde el lenguaje de las variables. Lo que permanece entonces son descripciones elocuentes e interpretaciones razonables de lo que la variable "género" puede decirnos acerca de la orientación del voto del electorado en general, y del voto femenino en particular. De allí entonces el interés de detenerse en aquellas investigaciones que presumen que los electores emiten sus prefe- 
rencias de modo racional, en la medida en que la hipótesis de racionalidad postulada supone que "la coherencia de las elecciones que son guiadas por la razón, es en cualquier caso requerida a partir del momento en que las acciones humanas son tomadas como objeto de estudio, aceptando tanto la hipótesis de una libertad de elección como un principio causalista de explicación” (Gérard-Varet y Passeron, 1995, p. 11). Si bien esta hipótesis es postulada en numerosos estudios, su presencia es a menudo meramente retórica, como si su enunciación fuese el precio a pagar para acceder a la legitimidad científica. Tal es el caso de Navia (2004), quien se propone estudiar la participación electoral en Chile "como una función basada en costos y beneficios que hacen que ciudadanos racionales decidan si votar o abstenerse” (p. 82), en circunstancias que este supuesto no es nunca abordado en una investigación que es por lo demás sumamente interesante. No muy distinto es el caso de Montes, Mainwaring y Ortega (2000), quienes, trabajando sobre la idea de "fuerza y debilidad" de un partido (p. 797), intentan evaluar la capacidad de atracción partidaria de "votantes leales que se identifican con el partido en un periodo extendido" de tiempo" (p. 797), explicitando una serie de condiciones, dos de las cuales presuponen un comportamiento racional de los electores: en primer lugar, presuponiendo que "los incentivos para la votación estratégica son fuertes cuando la magnitud distrital es de uno" y en donde existen "reglas de pluralidad", lo que significa que este tipo de votación se torna menos plausible a medida que se avanza hacia magnitudes distritales superiores (p. 797); y en segundo lugar, hipotetizando que el sufragio le debe permitir al votante cruzar su voto por varias posiciones (p. 798). En ambos trabajos, lo que se aprecia es una hipótesis de racionalidad que nunca es testeada como tal, sino que su existencia es supuesta a partir de los resultados a los que llegan los autores por otras vías: en el caso de Navia (2004), para superar el carácter meramente descriptivo de los datos electorales que él proporciona acerca de la evolución de la participación electoral observada en Chile a partir de 1990, especialmente en materia de inscripción en los registros electorales sobre la población en edad de votar (PEV); en el caso de Montes, Mainwaring y Ortega (2000), con el fin de caracterizar el sistema de partidos en Chile.

Puede entonces entenderse que en la discusión sobre los efectos del sistema binominal chileno esté también presente la hipótesis de racionalidad, con el fin de volver verosímil tanto las estrategias de los candidatos como (sobre todo) el comportamiento de los votantes. En este último caso, el supuesto de racionalidad desempeña la función de orientar, y ajustar, el comportamiento de los electores a las propiedades formales del sistema binominal de acuerdo con una lógica de incentivos desde la cual se entien- 
de tanto la oferta de candidatos vinculados a partidos o coaliciones, como las orientaciones de voto resultantes. De este modo, resulta perfectamente congruente con la lógica formal del sistema binominal afirmar que sea "muy poco probable que un votante racional continúe favoreciendo a un partido o candidato que no tenga oportunidades realistas de ganar" (Payne, Zovatto, Carrillo y Allamand, 2003, p. 92). Esta apreciación, pudiendo ser cierta desde el punto de vista de los incentivos formales a los que se enfrentan los electores, resulta ser definitivamente inverosímil, a la vez que irrealista, desde la perspectiva empírica de los comportamientos electorales, puesto que un supuesto de conducta de esta naturaleza no permite comprender ni las preferencias electorales emitidas por candidatos de una misma lista que poseen probabilidades de éxito electoral cercanas a cero (especialmente en los distritos en donde la distribución histórica de los votos no permite albergar expectativas de doblaje a favor de una u otra lista, y sobre todo cuando uno de los candidatos es un incumbente de quien sabemos — gracias al trabajo de Cabezas y Navia (2005) — posee una elevada chance de seguir en posesión del único escaño que es razonablemente conquistable por una u otra de las listas en competencia), ni menos entender la conducta de voto de aquellos electores que optan por candidatos independientes o comunistas. Todo indica, por consiguiente, que el supuesto de racionalidad del comportamiento electoral de los votantes apunta a producir las condiciones de conversión de los efectos mecánicos y esperados del sistema binominal en efectos si no empíricos, a lo menos verosímiles.

Muy distinto sería si el postulado de racionalidad de los agentes fuese directamente testeado, y no inferido de resultados electorales o políticos sobre los que recae una interpretación racional de las conductas subyacentes. En tal sentido, el trabajo de Rahat (2004) referido a las reformas electorales emprendidas en cuatro democracias consolidadas (Japón, Israel, Italia y Nueva Zelanda) es admirable, puesto que el autor explica cada una de estas reformas relativizando la hipótesis de racionalidad de los legisladores, al poner en evidencia el hecho de que "las percepciones, las motivaciones y los comportamientos de los actores cambiaron continuamente a lo largo del tiempo" (p. 462). Sin descuidar completamente la hipótesis de racionalidad de los legisladores, Rahat emplea una concepción mucho menos rígida y exigente, puesto que en los cuatro casos estudiados, las reformas promovidas desembocaron en la adopción de sistemas electorales mixtos, lo que expresa "un real elemento de compromiso" (p. 474), en el cual podemos suponer — si de lo que se trata es preservar la hipótesis de racionalidad, una opción que no es la de Rahat, quien aboga por aproximaciones alternativas mediante el empleo de "métodos y enfoques histórico-comparados 
más flexibles” (p. 475) — que convergen intereses y preferencias que variaron en el tiempo, a través de un esfuerzo de adaptación a las lógicas y al ritmo de los procesos de reforma.

\section{Conclusión}

Si a lo largo de estas páginas ha sido posible poner en evidencia los supuestos y premisas sobre los que descansa la demostración de un "efecto", de un "comportamiento" o del funcionamiento de un "sistema" sin que éstos estén siempre justificados y avalados por (buenas) razones, ello se debe a la empresa de deconstrucción que aquí hemos ensayado. Como tal, se trata de un ejercicio que restituye el razonamiento de los autores, destacando todo lo que se gana y se pierde con la elección de nociones y categorías que a menudo adoptan la fisonomía pre-científica de la palabra, del adjetivo y hasta de la adjetivación, pero no siempre la del concepto. No puede ser, entonces, una sorpresa que al término de este ejercicio lo que predomine sea un cierto sentimiento de insatisfacción, no porque se trate de investigaciones incorrectamente realizadas, sino porque éstas a veces carecen de vigilancia conceptual y de espíritu teórico en diversos momentos de la reflexión. En tal sentido, la deconstrucción suele coincidir con la desmitificación, con todos los costos para el conocimiento presuntamente conquistado que esto puede significar.

Pero el efecto desmitificador también se explica por los límites inherentes al lenguaje de las variables y de la razón cifrada. Los números y las estadísticas, es obvio señalarlo, son signos y símbolos que permiten formalizar resultados y acceder a determinados niveles de abstracción, en una escena intelectual en donde existe una recompensa para aquellos que asocian la definición de la ciencia política y social con la medición. Si es posible criticar aquellas escrituras de la historia política del presente que se despliegan a partir de correlaciones estadísticas y de modelos formales o espaciales, es porque se trata de escrituras totalizadoras que sitúan en un tiempo y un espacio único a hechos, sucesos, acciones y significados que no sólo no se forjaron simultáneamente, sino que son el resultado de encadenamientos cuya trama es posible revelar a partir de una mirada propiamente histórica que no puede soslayar el lenguaje natural de quienes participaron - sin necesariamente saberlo - en procesos que carecen de fines respecto de los cuales los actores se presume tendrían una clara y diáfana "conciencia”. En tal sentido, los cuadros de resultados que agrupan votaciones, escaños o correlaciones son un procedimiento gráfico que permite ver en un solo momento lo que es la consecuencia de miles de pequeños compor- 
tamientos que han tenido lugar en distintos momentos del tiempo. No hay nada ilegítimo en este ejercicio de presentación y formalización gráfica de los resultados a los que llega el investigador, salvo que, "debido a su carácter bidimensional y fijo", éste tiende a simplificar la realidad, "al punto de volverla prácticamente irreconocible, reduciendo entonces nuestra comprensión en lugar de aumentarla” (Goody, 1979, p. 111). ¿De qué manera? Mediante la reconversión de las racionalidades y de los resultados prácticos que son elaborados por los agentes, sean éstos coaliciones, partidos, dirigentes políticos y electores comunes y corrientes, en un lenguaje estadístico totalizador que hace caso omiso de la historicidad y de los contextos desde los cuales se elaboran estrategias políticas o de campaña, se forman listas de candidatos, se construyen alianzas y se emite un sufragio. Como bien lo dice Goody, "se puede sin duda simplificar lo que es la realidad para el observador, pero a menudo es en desmedro de una verdadera comprensión del marco de referencia del actor” (p. 139).

De lo anterior no se puede concluir, sin embargo, que el pensamiento estadístico sea un enemigo del espíritu científico. Muy por el contrario. A menudo resulta imposible superar el juicio anecdótico e individual sobre asuntos particulares sin la mediación del razonamiento gráfico y de su objetivación numérica y cifrada. Simplemente, conviene estar atento al fuerte reduccionismo al que puede conducir el trabajo de medición cuando en él se encuentran ausentes el pensamiento teórico y el vocabulario conceptual con el que interrogamos el lenguaje natural desde el cual la política y sus objetos se hacen y construyen. Es esta tensión entre el lenguaje de las variables, el pensamiento teórico y el idioma natural de los agentes del mundo político y social que es tan propia del trabajo científico en ciencias sociales, la que es señalada con elegancia y brillantez por Desrosières: "la pregunta no consiste en saber si una ciencia pura y autonomizada de sus usos impuros es concebible, incluso a título de ideal-límite imposible de alcanzar. Se trata más bien de estudiar cómo la tensión entre, por una parte, la reivindicación de objetividad y de universalidad y, por la otra, la articulación fuerte con el universo de la acción se encuentra en el origen de la propia dinámica de la ciencia y de las transformaciones y retraducciones de sus esquemas cognitivos y de sus instrumentos técnicos" (Desrosières, 2000, p. 14). Si este artículo ha logrado incomodar a quienes cultivan diestramente la ciencia política por la vía de la medición sin concepto, de la construcción de correlaciones sin preguntas teóricas de por medio, entonces eso quiere decir que se ha logrado perturbar la suave rutina de los hábitos mentales que llevan a creer que la cifra, el número y la fórmula bastan para asentar una definición de lo que hacer ciencia política y social quiere decir. 


\section{REFERENCIAS}

Altman, David (2004): "Redibujando el Mapa Electoral Chileno: Incidencia de Factores Socioeconómicos y Género en las Urnas”. En Revista de Ciencia Política, Vol. XXIV, No 2, pp. 49-66.

(2005): "Reforma al Binominalismo: Sistema Paralelo de Acumulación”. Documento de Trabajo $\mathrm{N}^{\circ}$ 2, septiembre, Santiago, Instituto de Ciencia Política de la Pontificia Universidad Católica de Chile.

Barozet, Emanuelle y Marcel Aubry (2005): “De las Reformas Internas a la Candidatura Presidencial Autónoma: Los Nuevos Caminos Institucionales de Renovación Nacional”. En Política, Vol. 45, primavera, pp. 165-196.

Bermeo, Nancy (2003): Ordinary People in Extraordinary Times. The Citizenry and the Breakdown of Democracy. Princeton y Oxford: Princeton University Press.

Boudon, Raymond (1997): “Le 'Paradoxe du Vote’ et la Théorie de la Rationalité". En Revue Française de Sociologie, XXXVIII, pp. 217-227.

Bourdieu, Pierre (1979): La Distinction. Critique Sociale du Jugement. París: Minuit.

_ (1981): "La Représentation Politique. Eléments pour une Théorie du Champ Politique”. En Actes de la Recherche en Sciences Sociales, 36/37, février-mars, pp. 3-24.

(1982): “Les Rites Comme Actes d'Institution”. En Actes de la Recherche en Sciences Sociales, 43, pp. 58-63.

(1984): Questions de Sociologie. París: Seuil.

Bourdieu, Pierre, Jean-Pierre Passeron y Jean-Claude Chamboredon (1968): Le Métier de Sociologue. París: Mouton-Bordas.

Cabezas, José Miguel y Patricio Navia (2005): "Efectos del Sistema Binominal en el Número de Candidatos y de Partidos en Elecciones Legislativas en Chile, 19892001”. En Política, Vol. 45, primavera, pp. 29-51.

Cantillano, Priscilla y Patricio Navia (2005): "Representación y Tamaño de los Distritos Electorales en Chile, 1988-2004”. Documento de Trabajo $N^{\circ}$ 1, Año 1, julio, Santiago, ICSO-Universidad Diego Portales.

Carey, John M. y Peter M. Siavelis (2005): "Insurance for Good Losers and the Survival of Chile’s Concertación”. En Latin American Politics and Society, Summer, Vol. 47, No 2, pp. 1-22.

Colomer, Josep M. (2004a): "Taming the Tiger: Voting Rights and Political Instability in Latin America”. En Latin American Politics and Society, Summer, Vol. 46, $\mathrm{N}^{\circ}$ 2, pp. 29-58.

(2004b): "Making Sense of a Model: A Response to J. Samuel Valenzuela". En Latin American Politics and Society, Summer, Vol. 46, No 2, pp. 69-72.

- (2004c): Cómo Votamos. Los Sistemas Electorales del Mundo: Pasado, Presente y Futuro. Barcelona: Gedisa.

Desrosières, Alain (2000): La Politique des Grands Nombres. Histoire de la Raison Statistique. París: La Découverte.

Dow, Jay K. (1998): “A Spatial Analysis of Candidate Competition in Dual Member Districts: The 1989 Chilean Senatorial Elections”. En Public Choice, 97, pp. 451-474.

Downs, Anthony (1957): An Economic Theory of Democracy: Nueva York: Harper Collins Publishers. 
Duverger, Maurice (1976): Les Partis Politiques. París: Armand Colin.

FLACSO (2006): Una Reforma Necesaria: Efectos del Sistema Binominal. Santiago: FLACSO.

Fornos, Carolina A., Timothy J. Power, y James C. Garand (2004): "Explaining Voter Turnout in Latin America, 1980 to 2000”. En Comparative Political Studies, Vol. 37, 8, October, pp. 909-940.

Gaxie, Daniel (2003): La Démocratie Représentative. París: Montchrestien (4a edición).

Gérard-Varet, Louis-André y Jean-Claude Passeron (bajo la dirección de): Le Modèle et l'Enquête. Les Usages du Principe de Rationalité dans les Sciences Sociales. París: EHESS.

Goertz, Gary (2005): Social Science Concepts: A User's Guide. Princeton: Princeton University Press.

Goody, Jack (1979): La Raison Graphique. La Domestication de la Pensée Sauvage. París: Minuit.

Guzmán, Eugenio (1993): “Reflexiones sobre el Sistema Binominal”. En Estudios Públicos, 51, pp. 303-325.

Joignant, Alfredo (2000): “Agent, Structure et Cognition. Questions de Recherche à Partir de la Sociologie de Pierre Bourdieu et Anthony Giddens”. En Cahiers Internationaux de Sociologie, CVIII, pp. 187-196. - (2001): "El Lugar del Voto. La Ley Electoral de 1874 y la Invención del Ciudadano-Elector en Chile”. En Estudios Públicos, 81, verano, pp. 245-275. - (2002): “Un Sanctuaire Électoral. Le Bureau de Vote et l'Invention du Citoyen-Électeur au Chili à la Fin du XIXème Siècle”. En Genèses. Sciences Sociales et Histoire, 49, décembre, pp. 29-47.

(s/f): "Les Grammaires de la Compétence Politique. Repères, Langages et Scripts”. Manuscrito no publicado.

Joignant, Alfredo y Miguel Ángel López (2005): “Le Comportement Électoral au Chili: Paradoxes et Présomptions sur la Continuité ou la Rupture de l’Orientation du Vote”. En Problèmes d'Amérique Latine, 56, printemps, pp. 63-80.

Joignant, Alfredo y Amparo Menéndez-Carrión (1999): "De la 'Democracia de los Acuerdos’ a los Dilemas de la Polis: ¿Transición Incompleta o Ciudadanía Pendiente?”. En Amparo Menéndez-Carrión y Alfredo Joignant (editores), La Caja de Pandora. El Retorno de la Transición Chilena. Santiago: PlanetaAriel.

Joignant, Alfredo y Patricio Navia (2003): “De la Política de Individuos a los Hombres del Partido. Socialización, Competencia Política y Penetración Electoral de la UDI (1989-2001)”. En Estudios Públicos, N 89, verano, pp. 129-171.

Jones, Mark P. y Scott Mainwaring (2003): "The Nationalization of Parties and Party Systems. An Empirical Measure and an Application to the Americas”. En Party Politics, Vol. 9, No 2, pp. 139-166.

Laakso, Markku y Rein Taagepera (1979): “'Effective’ Number of Parties. A Measure with Application to West Europe”. En Comparative Political Studies, Vol. 12, $\mathrm{N}^{\mathrm{o}}$ 1, April, pp. 3-27.

Lagroye, Jacques (1994): Sociología Política. Buenos Aires: Fondo de Cultura Económica. (bajo la dirección de) (2003): La Politisation. París: Belin. 
Lazarsfeld, Paul (1970): “Observations Historiques sur la Formation et la Mesure des Concepts dans les Sciences du Comportement”. En Paul Lazarsfeld, Philosophie des Sciences Sociales. París: Editions Gallimard.

Lewis, Paul H. (2004): “The 'Gender Gap’ in Chile”. En Journal of Latin American Studies, $N^{\circ} 36$, pp. 719-742.

Lindholm, Charles (1992): Carisma. Análisis del Fenómeno Carismático y su Relación con la Conducta Humana y los Cambios Sociales. Barcelona: Gedisa.

Linz, Juan J. (1987): La Quiebra de las Democracias. Madrid: Alianza Editorial.

Lipset, Martin Seymour y Stein Rokkan (1967): Party Systems and Voter Alignments: Cross-National Perspectives. Nueva York: The Free Press.

Magar, Eric, Marc R. Rosenblum y David Samuels (1998): “On the Absence of Centripetal Incentives in Double-Member Districts: the Case of Chile”. En Comparative Political Studies, Vol. 31, No 6, December, pp. 714-739.

Milner, Henry (2004): La Compétence Civique. Comment les Citoyens Informés Contribuent au Bon Fonctionnement de la Démocratie. Les Presses de l’Université Laval.

Montes, J. Esteban, Scott Mainwaring y Eugenio Ortega (2000): "Rethinking the Chilean Party Systems”. En Journal of Latin American Studies, 32, pp. 795824.

Munck, Gerardo L. y Jay Verkuilen (2002): “Conceptualizing and Measuring Democracy. Evaluating Alternative Indices”. En Comparative Political Studies, Vol. 35, February, pp. 5-34.

Navia, Patricio (2003): “Comportamiento Electoral con Miras a las Municipales 2004”. En Perspectivas, Vol. 6, No 2, pp. 267-291.

(2004): “Participación Electoral en Chile, 1988-2001”. En Revista de Ciencia Política, Vol. XXIV, 1, pp. 81-103.

Navia, Patricio y Alfredo Joignant (2000): “Las Elecciones Presidenciales de 1999: La Participación Electoral y el Nuevo Votante Chileno". En varios autores, Nuevo Gobierno: Desafíos de la Reconciliación Chile 1999-2000. Santiago: FLACSO.

Offerlé, Michel (1987): Les Partis Politiques. París: Presses Universitaires de France.

Panebianco, Angelo (1990): Modelos de Partido. Organización y Poder en los Partidos Políticos. Madrid: Alianza Editorial.

Panzer, John y Ricardo Paredes D. (1991): “The Role of Economic Issues in Elections: the Case of the 1988 Chilean Presidential Referendum”. En Public Choice, 71, pp. 51-59.

Paramio, Ludolfo (2000): “Clase y Voto: Intereses, Identidades y Preferencias”. En Revista Española de Investigaciones Sociológicas, 90, pp. 81-95.

Passeron, Jean-Claude (1991): Le Raisonnement Sociologique. L'Espace Non-PoppéRien du Raisonnement Naturel. París: Nathan.

Pastor, Daniel (2004): “Origins of the Chilean Binominal Election System”. En Revista de Ciencia Política, Vol. XXIV, No 1, pp. 38-57.

Payne, J. Mark; Daniel Zovatto G., Fernando Carrillo Flórez y Andrés Allamand Zavala (2003): La Política Importa. Democracia y Desarrollo en América Latina. Washington D.C.: Banco Interamericano de Desarrollo e Instituto Internacional para la Democracia y la Asistencia Electoral.

PNUD (2004): La Democracia en América Latina. Hacia una Democracia de Ciudadanas y Ciudadanos. Programa de Naciones Unidas para el Desarrollo. 
Rabkin, Rhoda (1996): "Redemocratization, Electoral Engineering, and Party Strategies in Chile, 1989-1995”. En Comparative Political Studies, Vol. 29, 3, June, pp. 335-356.

Rahat, Gideon (2004): "The Study of the Politics of Electoral Reform in the 1990s. Theoretical and Methodological Lessons”. En Comparative Politics, Vol. 36, 4, July, pp. 461-479.

Sartori, Giovanni (1980): Partidos y Sistemas de Partidos. Madrid: Alianza Editorial.

Scully, Timothy R. y J. Samuel Valenzuela (1993): “De la Democracia a la Democracia. Continuidad y Variaciones en las Preferencias del Electorado y en el Sistema de Partidos en Chile”. En Estudios Públicos, 51, invierno, pp. 195-228.

Siavelis, Peter M. (1997): "Continuity and Change in the Chilean Party System. On the Transformational Effects of Electoral Reform”. En Comparative Political Studies, Vol. 30, No 6, December, pp. 651-674.

Siavelis, Peter M. (2002a): "Coalition, Voters and Party System Transformation in Post-authoritarian Chile”. En Government and Opposition, Vol. 37, $\mathrm{N}^{\mathrm{o}} 1$, Winter, pp. 76-105.

(2002b): "The Hidden Logic of Candidate Selection for Chilean Parliamentary Elections”. En Comparative Politics, Vol. 34, № 4, July, pp. 419-438.

- (2005a): "Electoral System, Coalitional Desintegration, and the Future of Chile’s Concertación”. En Latin American Research Review, Vol. 40, N 1, February, pp. 56-82.

(2005b): "Los Peligros de la Ingeniería Electoral y de Predecir sus Efectos". En Política, Vol. 45, primavera, pp. 9-28.

Simon, Herbert A. (1984): Models of Bounded Rationality. Vol. I: Economic Analysis and Public Policy. Mass.: MIT Press.

Tironi, Eugenio y Felipe Agüero (1999): “¿Sobrevivirá el Nuevo Paisaje Político Chileno?”. En Estudios Públicos, 74, otoño, pp.151-168.

Torcal, Mariano y Scott Mainwaring (2003): “The Political Recrafting of Social Bases of Party Competition: Chile, 1973-95”. En British Journal of Political Science, Vol. 33, № 1, January, pp. 55-84.

Valenzuela, Arturo (s/f): El Quiebre de la Democracia en Chile. Santiago: FLACSO.

Valenzuela, J. Samuel (1995): “Orígenes y Transformaciones del Sistema de Partidos en Chile”. En Estudios Públicos, 58, otoño, pp. 5-80. (1998): "La Ley Electoral de 1890 y la Democratización del Régimen Político Chileno”. En Estudios Públicos, 71, invierno, pp. 265-296.

(2004): "Making Sense of Suffrage Expansion and Electoral Institutions in Latin America: A Comment on Colomer's 'Tiger'”. En Latin American Politics and Society, Vol. 46, N² 2, Summer, pp. 59-67.

(2005): “¿Hay que Eliminar el Sistema Binominal? Una Propuesta Alternativa”. En Política, Vol. 45, primavera, pp. 53-66.

Weber, Max (1995): Economie et Société. Tomos 1 y 2. París: Plon. $\square$ 